Federal Reserve Bank of Dallas

Globalization and Monetary Policy Institute

Working Paper No. 29

http://www.dallasfed.org/assets/documents/institute/wpapers/2009/0029.pdf

\title{
Monetary Policy Strategy in a Global Environment*
}

\author{
Philippe Moutot \\ European Central Bank \\ Giovanni Vitale \\ European Central Bank
}

March 2009

\begin{abstract}
Since the mid-1980s the world economy has gone through profound transformations of which the sources and effects are probably not yet completely understood. The process of continuous integration in trade, production and financial markets across countries and economic regions - which is what is generally defined as "globalisation" - affects directly the conduct of monetary policy in a variety of respects. The aim of this paper is to present an overview of the structural implications of globalisation for the domestic economies of developed countries and to deduct from these implications lessons for the conduct of monetary policy, and in particular the assessment of risks to price stability.
\end{abstract}

JEL codes: E5, F4

\footnotetext{
* Philippe Moutot, European Central Bank, Kaiserstrasse 29, D-60311 Frankfurt am Main, Germany. Philippe.Moutot@ecb.int. Giovanni Vitale, European Central Bank, Kaiserstrasse 29, D-60311 Frankfurt am Main, Germany. Giovanni.Vitale@ecb.int. We thank participants at the International Conference of the Banque de France for comments on an early draft in 2007. All errors are ours. We thank A. Dalamangas for helpful research assistance. The views in this paper are those of the authors and do not necessarily reflect the views of the European Central Bank, the Eurosystem, the Federal Reserve Bank of Dallas or the Federal Reserve System.
} 


\section{Introduction}

Since the mid-1980s the world economy has gone through profound transformations of which the sources and effects are probably not yet completely understood. The process of continuous integration in trade, production and financial markets across countries and economic regions - which is what is generally defined as "globalisation" - affects directly the conduct of monetary policy in a variety of respects. The aim of this paper is to present an overview of the structural implications of globalisation for the domestic economies of developed countries and to deduct from these implications lessons for the conduct of monetary policy, and in particular the assessment of risks to price stability.

The most prominent stylised fact in the last 25 years is, from the point of view of the economic literature, that the level of inflation and its variability around this level has declined in both developed and, at some later stage, developing economies, leading several scholars and professionals to refer to this phenomenon as the "Great Moderation". ${ }^{1}$ But other developments have gradually added up and also need to be taken into account. They include global imbalances that have appeared in the current accounts of some large countries as well as the recurrence of booms and busts with global consequences over the last decade and the more recent acceleration and fall of commodity prices, which has ended or, at least, interrupted the "Great Moderation".

The debate has thus long focused on three possible interpretations of the Great Moderation: structural change, higher ability of policymakers and, more simply, good luck. Globalisation and its initial impact on import prices in particular, may have played a role in the first and the latter explanation either by changing the structure of the domestic economies involved in international trade or by exerting a somehow "mechanic" downward pressure on inflation trends. This paper reviews the theoretical arguments and the empirical evidence supporting one or the other hypothesis, without presuming that they are mutually exclusive. In doing so, the paper investigates the wider implications of the associated changes in the adjustment mechanism of the national economies to exogenous shocks and monetary policy actions. We will argue that the three explanations above are inter-related and that, in the future, they may play in many other ways than lately experienced. In particular, the recent increase in oil and other commodity prices constitute important, different, and immediate tests for monetary policy in which, some of the lessons above may have to be taken into account.

\footnotetext{
${ }^{1}$ See among the others, McConnell,and Perez-Quiros (2000) and Blanchard and Simon (2001).
} 
The paper also refers to another less studied stylized fact, the decrease of the home bias over the same period, and to other associated characteristics of financial flows including the high recurrence of asset price bubbles. Another feature of globalisation over the last ten years is a simultaneous increase of, on the one hand, pegs to the dollar and currency boards to the euro and on the other hand, of central banks targeting inflation. A related feature of globalisation is the change, in terms of relative size and financial power, of emerging countries and developed countries. While the US economy dwarfed both European and developing economies after the Second World War and until the 90's, the end of the last century witnessed the emergence of countries of large size like India, China, Russia and Brazil. This decrease of the home bias, the diffusion of monetary policy strategies targeting inflation or pegging to a major currency and the new distribution of financial power not only change the impact of capital flows, but also affect the dynamics of exchange rates and more generally of international adjustments, including global imbalances and financial crises. These elements also have consequences for the conduct of monetary policy, its ability to anticipate and react to international crises, and the nature of international surveillance.

The paper is organised as follows: the next section briefly reviews the literature studying the impact on inflation of the integration of new and low-wage countries into the global market. The main conclusion of this literature is that at least part of the decline in inflation in the developed economies up to 2007 would be explained by the downward pressure exerted by lower import prices on domestic inflation which has recently been balanced by the upward pressure of high commodity prices. In section 3 , the paper reviews the possible structural changes in the real sector that, on top of the relative decline of import prices, could have been responsible for a more structural decline in national inflation across the world. Section 4 extends the discussion about the structural implications of globalisation to the financial sector. In particular, the section distinguishes between the eventual change in the "home bias" and in the allocation of domestic savings and, more generally, the macroeconomic implications of the high level of integration of worldwide financial markets. Section 5 gathers various implications of globalisation for monetary policy. Section 6 draws the main messages. First, national monetary policy strategies must include the structural analysis of economic developments, in order to disentangle the possible shocks hitting the economy. In particular, the role of financial markets in the transmission of such shocks needs to be taken into account as their evolution and global integration is likely to play a significant role in the creation and distribution of liquidity across countries. The increased role of financial markets in the transmission mechanism provides further support to "leaning against the wind" of possible asset price bubbles. Second, the interdependence of financial markets across the globe strengthens the case of a new, more refined multilateral policy co-operation that integrates financial markets and international capital flows with economic developments and policy stances. 


\section{Globalisation as a negative then positive shock on inflation}

The first possible explanation of the link between globalisation and inflation is that the former has, at least in the beginning, generated a persistently negative shock on the inflation process in the developed economies, without altering the structure of the process itself. The argument would start from one significant aspect of globalisation: the size of the increase in the global supply of labour, which with the integration of China, India and Eastern Europe (EE) in the global economy has increased to 3.0 billions from 1.5 billions. ${ }^{2}$ Furthermore, due to the relatively low level of developments of those countries, the increase in global labour supply has increased the ratio of unskilled labour to skilled labour. Hence, wages of unskilled workers in the industrialised countries have declined relative to the wage of skilled workers and the rate of profit of capital has increased. Moreover, due to the secular decline in transportation costs and communication, firms have also relocated the production of goods (and services) that have low skilled labour content towards the newly emerging countries, while the production of goods (and services) with high skilled labour content would have shifted towards industrialised countries. In fact, technological developments have run so fast that for many goods and services it is now possible to allocate different stages of the production chain in different parts of the globe, depending on their relative content of skilled or unskilled labour. As a result, in all major OECD economies import prices have declined relative to domestic producer prices in the last 20 years. Pain et al. (2006) (PKS) calculates that over the period 1996-2005, the increasing integration into world trade of non-OECD economies, China and other Asian economies in particular, has reduced annual domestic inflation by 0.2 percentage points, on average, in both the US and the euro area, respectively. ${ }^{3}$ The dampening of inflation dynamics in the US and the euro area is due to both high import penetration from those low-cost producing countries and the relatively lower growth of Asian export prices compared to US and euro area producer prices. ${ }^{4}$ Isolating the effect of higher import penetration, which more closely measures the impact of globalisation, PKS (2006) estimates that the increasing share of imports from China and other Asian economies accounts for most of the total disinflationary effect in the euro area $(0.2 \%$ per annum, on average) over the period 1996-2005 but only the half of the total effect in the US (0.1\% per annum, on average).

\footnotetext{
${ }^{2}$ Bean (2006).

${ }^{3}$ PKS (2006) shows that while in the US the impact is evenly distributed over the decade under scrutiny, in the euro area the disinflationary effect is mainly concentrated over the period 2001-2005.

${ }^{4}$ In theory, a change in the share of external trade can affect domestic inflation through a "share" effect or a "price" effect. The share effect is defined as the change in euro area import prices due to the change in the import share of low-cost countries, while the price effect designates the contribution to total import prices due to import price inflation differentials between lowcost countries compared to that of high cost countries.
} 
Recent analysis undertaken at the $\mathrm{ECB}^{5}$ focuses on euro area external trade sector data in order to assess the impact of the increase in the share of external trade with China and the new EU member states on euro area prices. The input-output analysis reveals that over the period 1996-2004, the increasing share of external trade with China and the new EU member states can account for a roughly $1.5 \%$ per annum average reduction in import price inflation ${ }^{6}$ and in a $0.1 \%$ reduction in manufacturing producer prices in the euro area. The average effect on consumer prices inflation is estimated to be around $0.05 \%$ per annum. Using the results of a VAR model for the euro area production chain, ${ }^{7}$ which incorporates the "static" import price shock due to the "share" effect, the impact on consumer inflation is of around $0.3 \%$ per annum, on average, which is closer to the estimates reported in PKS (2006).

Furthermore, globalisation seems to have reduced the impact of exchange rate changes on euro area prices. ${ }^{8}$ The gradual and persistent decline of the US share in euro area imports may lead to a mechanical decline in import price exchange rate pass-through (ERPT) simply because US exports to euro area have high ERPT of around 90\%. However, the decline in the overall ERPT observed over the last 15-20 years may prove to be temporary and reverse once the price level of euro area imports from China and other developing economies catch up with the price level in other euro area import suppliers.

Overall, it is fair to say that since the mid-1990s globalisation has had a sizeable direct effect on domestic price inflation in the developed economies, which in the euro area has become more evident in the last five years. This direct effect could be expected to persist as long as cost differentials persist between the developed economies and the newly emerging economies, which could lead to further import penetration from these latter countries into the formers.

This however raises the question of how lasting the impact of such cost differentials will be. Will the decline in inflation prevail? Will its recent reversal last? Indeed, the increase in the supply of labour is accompanied by an increase in the global consumption of food, oil, and other commodities: the price of the latter have recently increased strongly and tangible counterbalancing effects on domestic inflation are already visible. This seems to be clearly the case already for oil and metal prices and is increasingly relevant for staples. Globalisation has not only led to a decline in the relative price of imports of manufactured goods and services but also - especially in the last 5 years - to an increase in oil and commodity prices largely due to higher global demand originating, inter alia from China and other Asian countries. Hence, in oil importing countries, like the US and the euro area, the decline in the relative price

\footnotetext{
${ }^{5}$ ECB (2006).

${ }^{6}$ The price effect (see footnote 5 ) would reduce import price inflation by another $0.5 \%$ per annum, on average.

${ }^{7}$ Pula and Skudelny (2007).

${ }^{8}$ Anderton (2007).
} 
of imported goods and services is, at least partially, compensated by the increase in commodities prices that is likely to dampen for a long period of time the beneficial effect of the decline in imported manufacturing goods and services on the workers' real wage. OECD-FAO (2008) argues that beyond temporary climatic factors the significant increase in commodities prices over the last two years is related to more permanent causes that are directly related to globalisation. First, there is the rapid income growth and dietary changes in developing, especially Asian, markets where demand of protein-rich products is raising thus putting upward pressure on prices of meat and of foodstuff needed to raise farm animals. Second, the direct effect of higher oil prices - that, in turn, are due to higher demand for energy arising in new developing, especially Asian, countries - that increase transportation and production costs. Third, the indirect effect of high oil prices that stems from the diversion of land and feedstocks away from food and into biofuels. Fourth, a counterbalancing effect on price competitiveness of developed countries which are more energy efficient than emerging countries and a lower impact on potential output which may end up decreasing the potential output growth differentials across these two categories of countries.

These developments would have at least two impacts of relevance to central bankers. First, they undermine the use and indicator value of core inflation. Indeed, if the evolution of items included in such concept becomes directly correlated with the evolution of items excluded, the notion of core inflation loses its meaning.. Second, the increase in oil and commodity prices - including food - may lower the real income of lower wage workers and increase their inflation perceptions, making the benefits of globalisation uneven, even when abstracting from production and competitiveness considerations. Moreover, by concentrating price increases on products frequently purchased, it may encourage a bias in perceptions that leads consumers to at least temporarily biased perceptions of their real income. To the extent that such perceptions may have an impact on the tendency to consume or save, on the support of the public for monetary policy and for the credibility of the central bank, this may also affect seriously the conduct of monetary policy. Furthermore, the acceleration in oil price increases in the beginning of 2008 - and its impact on headline price indexes in many economies -, confirms some recent empirical evidence $^{9}$ on the crucial role played by both monetary policies focussing on the maintenance of price stability and by the flexibility of real wages in facilitating the absorption of the oil price shock. Central banks may therefore have to recall the lessons of the 1970's oil price increases: the need to prevent second round effects, the need for wages to quickly absorb the corresponding real income loss, and the need for special communication in order to minimize gaps between perceptions of inflation and actual inflation.

\footnotetext{
${ }^{9}$ Blanchard and Gali, (2007).
} 


\section{Globalisation changes the structure of the real economy}

The decline in global inflation may have been related not only to the direct cyclical effect of globalisation on the relative price of imports - described in the previous section - but also to a permanent effect that globalisation may have had on the structure of the real economy, in particular on the price and wage formation mechanisms, in the developed economies.

\subsection{Is there a permanent effect on the level of output?}

At first, globalisation may have permanently increased the level of output that an economy can produce, without generating inflationary pressures. The argument runs from the decline in the relative price of imported goods that increases the workers' real wages without increasing the nominal costs for firms. Hence, for any nominal wage, the labour supply in the economy would increase because workers would be willing to work more for the same nominal wage and because new workers would be willing to work for lower nominal wages. This process entails a rightward shift of the "long-run" Phillips curve, which delivers both higher output growth and lower inflation.

However, this approach does not take into account the effect of oil prices and commodities mentioned above Also, the effect of oil and commodity prices on potential output may be significant in countries with low productivity growth. In the end, the net impact of globalisation is an empirical issue and for what concerns the euro area., the latest developments of nominal wages and labour costs suggest that wage negotiations are only starting to generate second round effects from past oil price increases... Moreover, the approach in the paragraph above may not give sufficient weight to competitiveness considerations. In fact, it is most valid for countries which benefit of a sufficient level of product and services specialisation in order to employ mostly skilled workers. And even in that case, this does not take into account the adjustment dynamics necessary to make use of such skills in new fields when technology and telecommunications make it possible to use low-skilled workers for traditional products or services.

Indeed, in those countries that are endowed with potentially skilled workers the adjustment needed to compete with new emerging countries entails an increase in the import content of domestic production, including in those sectors which sell their products in the global marketplace. Hence, in developed countries the export sector has to go through a phase of significant transitional unemployment and durably lower consumption of workers. Thus, the economy may take quite some time to come back to medium term potential output. The increase in firms' investment needed to maintain competitiveness is, in a first period, associated with diminishing production and only at a later stage do employment and consumption catch up. The example of Germany and more generally the euro area is in this context particularly notable. 
Finally, the increase of oil and other commodity prices may, if it is substantial and permanent, have an impact on the production function of many economies. It may thus counterbalance the positive effect of cheaper prices for other imports, at least for countries which are not well enough specialised or not sufficiently energy-efficient to take sufficient advantage of the latter. This may even lengthen the transitional process described above. In any case, the negative impact on the production function should reduce the output gap, thereby influencing inflation dynamics.

These adjustment dynamics have also consequences for monetary policy. First, indicators such as the "output gap" and the "NAIRU" may be biased to the extent that the usual statistical methods for their measurement are based on former and normally shorter cycles, which may result in a spurious amplification of both the decline and subsequent acceleration in trend dynamics. Second, the conduct of monetary policy may need to take into account the possibly prolonged adjustment in the export sector and tend to maintain lower interest rates during the downturn but increase them in the recovery period at levels and speed that could be higher than normal. This may explain, along with more traditional arguments the observation, since the start of this century, of a substantial deviation of observed policy rates in the major developed economies from the normative rate prescribed by standard Taylor rules estimated on historical data.

\subsection{A permanent effect on the shape of the Phillips curve?}

A different structural explanation of the observed trend decline in inflation in the last 20 years focuses on the impact of globalisation on the adjustment mechanism to demand shocks. In particular, it is argued that globalisation has increased the incentives for firms to absorb changes in demand by adjusting employment rather than the price for the final products. In other words, the short-run Phillips curve, which maps excess demand over supply ${ }^{10}$ into inflation, has flattened due to the increase in trade and production specialisation across countries. ${ }^{11}$

To be true, the empirical evidence concerning the eventual flattening of the Phillips curve remains rather controversial. Research conducted at the IMF and the BIS $^{12}$ finds support to the hypothesis that the

\footnotetext{
${ }^{10}$ And, in standard macroeconomic forward-looking models, inflation expectations.

${ }^{11}$ Gali and Monacelli (2005) model a small open economy trading with an infinite number of other foreign economies. In the Phillips curve of the model they show that the more open the economy is and the less substitutable domestic goods are with respect to foreign goods, the lower is the coefficient on the domestic output gap.

${ }^{12}$ IMF (2006) and Borio and Filardo (2007), respectively. Ciccareli, M. and B. Mojon (2005) also argue that in a sample of OECD economies domestic inflation is driven by a global inflation process, which at short horizons is a function of global real developments.
} 
increase in international trade and production specialisation has increased the importance of global indicators of economic slack and inflation relative to domestic indicators. However, Calza (2007) cannot find significant evidence of the impact of foreign variables on domestic inflation while Ihrig et al. (2007) show that the empirical estimates depend on the specification of the estimated Phillips curve.

In a recent paper Benati (2007) provides another possible explanation to the flattening of the Phillips curve, which is rooted into the main thrust of the New Keynesian framework. In the standard firms' pricing rule assumed in those models, higher (lower) trend inflation increases (decreases) the frequency of firms' price adjustments - which is a "deep" parameter entering the reduced form coefficient of the output gap in the Phillips curve - thus increasing (reducing) the sensitivity of domestic inflation to cyclical fluctuations of output. Benati (2007) shows that historically and across a large set of countries including the euro area, the time-varying slope of the Phillips curve is positively correlated to the trend rate of inflation. Hence, according to his interpretation, the decline in the coefficients of estimated reduced form Phillips curve for many OECD countries, including the euro area over the last two-three decades is due to the progressive affirmation of a low-inflation environment. Theoretically, the standard New Keynesian Phillips curve models inflation as a function of past and expected inflation plus some driving variable, which normally is the output gap or firms' marginal costs. Hence, assuming rational expectations and forward-looking behaviour the trend in inflation is affected by the trend in the driving variable. This would imply that globalisation may have contributed to flatten the short-term Phillips curve by influencing the trend of the driving variable - for example by affecting the trend of the domestic wage dynamics - rather than through the integration of the production process and increasing international trade. $^{13}$

An alternative explanation of the apparent flattening of the short-run Phillips curve is the reduced ability of firms to increase their mark-up in presence of aggregate demand shocks. ${ }^{14}$ In the New Keynesian framework the link between the fluctuations in aggregate demand and prices is provided by profit margins, or "mark-ups". The theory says that whenever the firms experience an unexpected increase in the demand for their product, their cost of production goes up and thus they increase prices to leave their margins unaltered. The competition from labour-abundant economies reduces the ability of firms to pass

\footnotetext{
${ }^{13}$ Benati (2007) estimates show that output gap coefficients, while being much lower than during the 1970s, are far from being zero, thus confirming that there still exist a short-run trade off between inflation and output in the sample of countries considered.

${ }^{14}$ Batini et al. (2005).
} 
the increase in costs to final product prices because otherwise they would lose market share. ${ }^{15}$ It is fair to argue that this explanation stands against the developments up to 2007 in the profit share in all major developed economies - and rising employment -, which have reached historical heights. This suggests that rather then compressing profit margins, global competitive forces have exerted downward pressures on the wage dynamics in developed economies thus reducing the effect of demand fluctuations on the cost of production directly. Furthermore, the fact that inflationary pressures arising from the sharp increase in oil prices over the past 2-3 years have had a relatively limited effect also suggests that shocks to the cost of production are up to now absorbed with a compression of the salary dynamics, rather than with an increase in final prices.

Overall, it seems to be true that the Phillips Curve has flattened. Although this may give a sense of comfort to central bankers, they also need to be aware that such Phillips curve may quickly see its slope change when the public learns about it. In such a context, the consequences in terms of output of accepting an inflation creep and thereafter having to combat it - the so-called "sacrifice ratio" - are also growing. ${ }^{16}$

However, the role of globalisation does not imply that global slack should be a major consideration, at least for large economies. Also, the impact of globalisation on import prices, which is a very relevant concern for small and medium-size economies, is less relevant for large economies. Moreover, the flattening of the Phillips Curve is also due to a combination of credibility and good luck. Indeed, globalisation may also have influenced the price setting behaviour of firms as mentioned by Benati. Finally, even if the flattening of the yield curve is purely connected to the increased credibility of central banks, some stroke of "bad luck" in the future cannot be excluded. Higher commodity prices, particularly if they affect the inflation perceptions of agents, could lead to a steepening of the Phillips curve.

\section{The globalisation of financial markets}

The progressive liberalisation of capital accounts that started in the 1980s in the developed economies and thereafter gradually involved also some of the more advanced emerging markets has, over the years, spurred the integration of world financial markets. The higher interdependence of financial markets and the accompanying financial innovation have changed the monetary transmission mechanism. It thereby

\footnotetext{
${ }^{15}$ Rogoff. (2003) argues that in fact globalisation may have had the opposite effect on firms' pricing behaviour. The argument is that the increase in competitive pressures arising from globalisation makes the cost for firms of setting the price at the wrong level much higher than in a situation of relatively lower competition. Hence, globalisation would lead firms to revise their prices more frequently and, eventually, increase the sensitivity of inflation - steepening the Phillips curve - to demand fluctuations.
}

\footnotetext{
${ }^{16}$ Viñals, J. (2000).
} 
poses new challenges to central banks that must interpret the developments in the domestic economy and, thus, assess their monetary policy stance.

Such challenges can be viewed as the results of an interaction among four main factors that characterise the latest developments in the globalisation process of financial markets. First, the home bias of investors has decreased, although in unequal manners across main countries. Second, the weight of global financial transactions relative to trade and services transactions has increased, thus giving at least in the short to medium term relatively more importance to financial determinants in driving the dynamics of exchange and interest rates. Third, such dynamics have been influenced by the diffusion across central banks of inflation targeting and currency board or pegging strategies. Fourth, the development of financial markets has spurred financial innovation and its diffusion, multiplying the techniques for the transfer of risks and thereby strengthening the channels of diffusion and transmission of financial shocks across sectors and countries.

In the following, we first analyse these stylised facts. Then we explain how their interaction may be at the source of a number of recent developments. We then describe how the assessments of global and national liquidity helps understand in due time such mechanisms, both at global level and at national level. Finally, we describe how high volatility in global financial markets, eventually exacerbated by the busting of asset price bubbles, affects the transmission process of economic shocks and pose peculiar challenges to the conduct of monetary policy.

\subsection{Four stylized facts of relevance to the functioning of global financial markets}

\section{a) The unequal reduction of the "home bias"}

Figure 1 below shows that over the period 1985-2004 the sum of foreign assets and liabilities over GDP in industrialised countries and in the emerging and developing countries increased by a factor higher than 3 and 1.5 , respectively.

\section{Insert Figure I here}

The rapid increase in the cross-border investment flows fostered by the liberalisation of national financial markets, in combination with the decline in communication costs and vibrant financial innovation has certainly contributed to reduce the so-called "home bias" of domestic investors over the last two decades.

To be true however, the process has not been homogeneous across countries, leading to an increased heterogeneity of participants in international financial markets. For instance in the US the diversification 
of residents' investments into foreign assets peaked around the mid-1990s ${ }^{17}$. In the rest of the industrialised countries and in those more advanced emerging economies that opened up to global capital markets the process started in the early 1990s and peaked around the beginning of the new decade when the correction in the US stock market led to the reversal of the financial flows from the rest of world into the US. ${ }^{18}$ Therefore, it is fair to say that since the mid-1990s the decline in the "home bias" at a global level has decelerated significantly. ${ }^{19}$

However, important structural factors remain that justify the persistence of financial flows from emerging and newly industrialised countries towards countries with more developed and deep financial markets. First, private investors from emerging countries who do not benefit in their home country from sufficiently liquid and safe financial markets would find it convenient to invest their funds into lower return foreign assets, either because they are less risky or because these assets would simply not be available in their home country. Second, official investors, like those Asian central banks of countries pegging their currency to the dollar would also invest into developed countries' financial assets-and not necessarily in dollar denominated assets- as a result of having sufficient reserves to guarantee the stability of such pegs. In particular, countries with excess savings and still embryonic financial markets have accumulated large amounts of official reserves, which are not necessarily managed in the same way as assets held by private investors. Hence, the relative size of players in global financial markets and their degree of risk aversion has become strongly heterogeneous, as shown by the emphasis given in media as well as by OECD and IMF to Sovereign Wealth Funds.

b) Financial versus trade and services transactions

Another stylised and related fact concerning global markets is that in developed economies, the size of financial transactions has grown a lot in comparison with the size of trade and services transactions.

\section{Insert Figure II here.}

This is the result of the continued deepening of developed financial markets and of the relentless financial innovation process as manifested by the significant growth in the size of their derivative markets. As a consequence, the role of global financial markets and their linkages in the transmission of economic shocks, both domestically and internationally, has increased substantially in the last decade and even

\footnotetext{
${ }^{17}$ Greenspan ,(2003).

${ }^{18}$ For what concerns the euro area, a further impulse to diversification for domestic investors was the introduction of the euro. In fact, the elimination of the intra-area exchange rate risk spurred foreign investment in debt instruments across euro area countries. Foreign investment in equities has been less pronounced as national stock markets remain rather segmented.

${ }^{19}$ Greenspan (2003).
} 
exchange rate movements across currencies with deep financial markets may now be driven more than in the past by global private and official portfolios reshuffling rather than current account positions. ${ }^{20}$

\section{c) The diffusion of inflation targeting and currency pegs in the context of central banking}

Since the mid 1990's, the diffusion of currency boards and of inflation targeting techniques across central banks has been fast.

\section{Insert Table I here.}

In the early 1990s, currency boards were viewed as miracle solutions to create monetary stability at low cost in emerging economies. Therefore currency boards pegging to the dollar and to the euro have proliferated. However, it has soon also appeared that they were sometimes attracting capital inflows invested in real estate or in low productivity projects financed in foreign currencies and thereby creating financial risks in case of appreciation of such currencies.

Then inflation targeting was successfully adopted by a number of central banks in developed and emerging countries. This monetary policy strategy, which is a practice recommended by the IMF, is hence now used by a majority of central banks. However, up to now, such inflation targeting has concentrated on the pursuit of price stability at horizons of two to three years, generally giving low weight to the need to monitor and possibly react to asset price developments.

It is all the more true that the diffusion of inflation targeting techniques has coincided with a debate on the need to "lean against the wind" concerning asset price bubbles which until mid 2007 mostly tilted in the direction of "inaction" under the influence of the Federal Reserve's and particularly of A. Greenspan's views. Indeed, it was believed that asset price disequilibria were impossible to identify at an early stage, that any action by the central bank would either be unsuccessful or harmful, and in the end would generate moral hazard.

However, as shown by Christiano et al. (2008) in a closed economy context, the very application of inflation targeting in a context of a rising bubble might lead to a policy stance actually encouraging the growth of asset price bubbles. ${ }^{21}$ This may explain that, as remarked by a number of observers, the

\footnotetext{
${ }^{20}$ Brender. and Pisani (2007).

${ }^{21}$ The logic of the argument relies on the stickiness of nominal wages, which do not increase sufficiently in response to an expected productivity shock, as it would in case wages were flexible. Hence, the required increase in the real wage can only occur through a decline in the inflation rate. But this would call the inflation targeter central bank to lower interest rates and then reinforce the stimulus effect arising on impact, from the expected increase in productivity. Such decline in the interest rate would also trigger a credit boom.
} 
occurrence of asset price bubbles may have increased in a context of low inflation where inflation targeting central banks are usually not sufficiently monitoring money and credit.

\section{d) financial innovation and the transfer of risks}

Lastly, over the last 20 years the integration of global financial markets has been accompanied by increasing financial development and liberalisation. In theory financial innovation, by deepening and completing financial markets is supportive of economic growth and improves the allocation of savings. New computing and information processing technologies have favoured the rise of new - often esoteric financial instruments explicitly designed to un-bundle and re-package the payoffs and the risks associated with primitive, more conventional, financial products and securities. Figure 3 below shows the rampant growth in the US first and in the Euro area after, of Asset Backed Securities (ABS) and Mortgage Backed Securities (MBS) issuances over the past 10 years. ${ }^{22}$

\section{Insert Figure III here}

This trend - originally aimed at a better sharing of risks across savers - was later extended to lending institutions in search of higher returns. That led to the exponential growth of credit derivatives, such as credit default swaps (CDS) and collateralised debt obligations (CDO). Figure IV documents the sudden and sharp increase in CDS and CDO global issuance over the last three years,. Their notional value in the first half of 2008 is estimated to have reached 54 trillion USD. ${ }^{23}$

\section{Insert Figure IV here.}

Together with many benefits like a better way for intermediaries to diversify risk, thereby reducing the transaction costs of investing and expanding access to capital, these developments went hand-in-hand with two side effects: a great increase in leverage and an unprecedented expansion of marketing for financial instruments.

The shift in banks' balance sheets away from holdings of relatively illiquid forms of assets (i.e. mortgage loans) to a business model whereby the banks originate an underlying loan which is then made tradable and negotiated in the open market (so-called "originate-and-distribute model") has made it harder to draw

\footnotetext{
${ }^{22}$ The Figure is based on a new dataset developed at the European Central Bank (see Poloni and Reynaud (2008)). The European Securitazion Forum (ESF (2008), Tables 2.1 and 2.2, page 5) calculates in 6.3 trillion $€$ the amounts outstanding at the end of the first quarter of 2008 of total ABS plus MBS in the US. Up to the same quarter, the total amount outstanding in Europe was of 1.2 trillion $€$. Data for the euro area are not available.

${ }^{23}$ International Swap and Derivatives Association (2008). Notice that in Figure IV the data for 2008 are estimates calculated in 2006.
} 
clear distinctions between previously distinct categories of financial players. New investors - notably hedge funds - have been born out of the need for market makers in previously unknown types of securities. But, more important perhaps, by allowing credit risk to be transferred across agents from different countries, it has also authorised the uncontrolled transfer of liquidity risks across countries and continents.

\subsection{How these four factors have interacted over the recent past}

The four stylised facts discussed above -and their interaction - provide one possible key for the interpretation of both the overall increase of inter-linkages across financial markets and the recent history of economic and financial tensions across large countries.

\subsubsection{The empirical evidence about the inter-linkages in global financial markets}

The liberalisation of cross-border capital flows and the vibrant developments in innovative financial markets in the last two decades combined to the increased readability of monetary policies aimed at price stability have facilitated and thereby increased the linkages between financial markets across the globe thus making the adjustment mechanism of domestic economies - and the monetary policy transmission mechanism - more prone to be affected by developments in foreign economies. The sheer size of global capital cross-border flows certainly influences the price of assets in any economy by contributing to determining both the supply and demand and the premiums that investors require for holding certain assets. ${ }^{24}$ There is a flourishing literature that supports the view that the transmission of financial markets developments across the world has increased in recent years. Domestic markets increasingly react to economic news expected to change the path of policy rates in some "centre" country, which is normally the United States.

Ehrmann et al. $(2005)^{25}$ underline the importance of international spill-overs, both within asset classes and across financial markets. Although the strongest international transmission of shocks takes place within asset classes, they find evidence that international cross-market spill-overs are significant, both statistically and economically. For instance, shocks to U.S. short-term interest rates exert a substantial influence on euro area bond yields and equity markets, and in fact, over the period 1989-2004, they

\footnotetext{
${ }^{24}$ Bernanke (2007).

25 The authors argue that an important share of the behaviour of financial markets is explained by foreign asset prices. On average, about 26 percent of movements in European financial assets are attributable to developments in U.S. financial markets, while about 8 percent of U.S. financial market shifts are caused by European developments. The larger importance of U.S. markets is found particularly for equity markets; for instance, movements in U.S. stock prices trigger corresponding change in the euro area, with more than 50 percent of the U.S. market developments being reflected in euro area stock prices. By contrast, European equities have an insignificant impact on their American counterparts.
} 
explain as much as 10 percent of overall euro area bond market movements. But the transmission of shocks also runs in the opposite direction as, in particular, short-term interest rates of the euro area have a significant impact on U.S. bond and equity markets. Furthermore, they show that in almost all cases the direct transmission of financial shocks within asset classes is magnified substantially, mostly by more than 50 percent, via indirect spill-overs through other asset prices. In a more recent contribution, Ehrman and Fratscher (2006) focus on the link between the US monetary policy and the stock market in foreign countries and they show that US monetary policy shocks have significant and in some cases sizable effects on foreign stock prices. Moreover, they provide supportive evidence to the fact that the US monetary policy shocks affect the foreign stock markets through foreign short-term interest rates and the exchange rate changes. Finally, they show that the sensitivity to US monetary policy shocks is higher in those countries that are more integrated globally - rather than only with the US - in real and financial terms. This latter result suggest that domestic financial conditions in any country do not necessarily depend on the financial conditions in the US market, which is the most developed and liquid in the world, but also on some sort of second round effects that are due to the complex web constituting the global financial and real linkages. ${ }^{26}$

\subsubsection{The stylised facts also help explaining recent financial tensions at global level}

The above mentioned four stylised facts can help explain some of the recent economic developments that have occurred both in single countries and at global level. First, as explained above, the decrease in the home bias in principle implies that domestic investors are able to reduce the risk of their portfolio without reneging on expected returns. ${ }^{27}$ Hence, the propagation of shocks hitting the economy through the financial system is likely to be smoother than it would be in case of lower country-diversification. Also, the stability of the financial system itself is in principle higher when financial shocks occur or the risk attitude among investors' changes. However, many elements may also make the benefits of its decrease volatile and actually generate costs. First, such benefits should be contrasted with the cost of the speculative bubbles which are inherent to the functioning of capital markets. A case in point is the burst of the 2001 bubble in the US stock market which coincided with a slowdown of growth in many countries. Another is the Asian crisis in 1998, which did not affect regional stock markets only but also local bond, debt, and exchange rate markets. The size of its costs for local economies led a number of affected countries in the region to switch to economic and financial policies aimed at accumulating

\footnotetext{
${ }^{26}$ In a more recent contribution, Bayoumi and Swinston (2007) analyse the transmission of movements between the real bond yields and inflation expectations across a number of countries. Based on high frequency data of inflation-indexed bonds they find that the causation in real bond yields goes univocally from the US to the other countries in the panel. The spillover in inflation expectations appear to be less important and the direction of causation is less clear.

${ }^{27}$ The seminal contribution is Markowitz (1952) that shows how the variance of a portfolio with the same mean return decreases when the correlation of the assets composing the portfolio declines. Grubel (1968) and Solnik (1974) are the first papers to illustrate how investing in foreign assets represents a possible diversification strategy that actually lowers the variance of a portfolio.
} 
substantial foreign exchange reserves. As to the current financial turmoil, which started as a localised real estate crisis, it affects the US, the Euro area and other European countries as a result of the recently developed risk transfer techniques not only through the dynamics of their respective exchange rates, but also through its impacts on the money bond and stock markets in both economic areas.

Second, the growing importance of international financial transactions over the last 25 years may imply that investors' behaviour and portfolio reshufflings could affect asset and foreign exchange markets in a novel way. Instead of reflecting fundamentals and their prospects, global asset and foreign exchange markets may in some instances be less volatile than normally expected over extended periods and thereafter evolve in a disorderly manner. This implies that several regimes of financial and foreign exchange market volatility may successively prevail. Figure $\mathrm{V}$ shows the standard deviation of asset and foreign exchange prices in selected markets. ${ }^{28}$ In both the US and the euro area stock markets the evidence of a "regime shift" occurring around the mid-1980s is quite evident. The same is true in the USD/EUR and the USD/JPY market, although the magnitude of the change is less sizeable. Furthermore, the scale of the charts of the foreign exchange markets hides the fact that over the last 15 years the volatility of the USD/JPY exchange rate is, on average, roughly 10 times as large as the volatility of the USD/EUR exchange rate.

\section{Insert Figure V here}

Indeed, if exchange rates are less driven by current account deficits or surpluses and more by capital flows and financial developments, the definition of their equilibrium levels becomes less precise. In particular, regimes of low exchange rate and financial markets volatility and regimes of high volatility can be at the same time more durable and alternate more swiftly. On the one hand, low exchange rate volatility seems to further encourage the decrease in "home bias" (ECB 2006) and therefore the seeming disconnection between traditional fundamentals and exchange rates, prolonging low volatility periods. The period 2004-2007 offered an example of such regime between large currencies, with low volatility of exchange rates prevailing despite strong current account imbalances, even in cases of large and nonfundamentally based exchange rate movements (Euro/Yen). At the same time, switches to high volatility regimes happen whenever unexpected financial developments lead to financial instability, itself resulting in exchange rate instability and a pause or a reversal in the decrease of the home bias. The periods between the US stock market crash and 2004 and also the developments since late 2007 offer such an example.

\footnotetext{
${ }^{28}$ The standard deviation plotted in the charts is computed over a 30-day moving window.
} 
Third, speculative bubbles and strong financial flows accompanied by low exchange rate volatility may develop, amplify and make large current account disequilibria - or "global imbalances" -.more persistent than usually expected. The US example is well known. The low exchange rate volatility combined to the desire of foreign governments in Asia and Opec to invest their reserves in dollars has led to an extremely low yield curve, especially at its long end. This has allowed for an easy financing of a real estate boom, leading in turn to an increase in US households' wealth that fostered private consumption growth and households' leverage at the cost of a continuous decrease in savings.

These developments are not dissimilar in their fundamental characteristics from what had already happened in the second half of the 1990s, when the high tech bubble in the US was substantially financed by speculative investments flows originating in Europe, where financial institutions and private investors used the opportunities of low interest rates to borrow in euro and invest in the technological sector of the US stock market. In other words, the issue of global imbalances appears as the outcome of a situation with the following characteristics: the combination of countries with excess savings and a country with low savings but an attractive financial centre leads to the development of an asset price movement. The latter allows for an increase of consumers' wealth which in turn justifies and perpetuates the lower savings - and the increasing leverage - of the low savings country.

Fourth, those countries experiencing low inflation and low volatility of the exchange rate are also more likely to be originators of capital flows that may ultimately fuel an asset price bubble in the destination country. As an example, the US stock market bubble that developed in the second half of the 1990s was partly financed close to its apex by Europe-based investors who were driven by the expectation of a protracted period of productivity growth in the US. At the time, the continuous depreciation of the euro versus the dollar provided further incentives for capital to flow from Europe into the US. Moreover, in the euro area interest rates were low and inflation developments were moderate and smooth, while US interest rates were relatively higher despite subdued price developments. Low inflation volatility periods may also facilitate large capital movements through so-called "carry trades", which may ultimately lead to large deviations of exchange rates from equilibrium. A recent and much discussed example is the carry trade organised by global financial investors by borrowing in Japanese yen and investing the proceedings in many other countries that were either following a successful inflation targeting strategy or with a currency board or a peg to a major currency. Once again, the low inflation and interest rate environment in Japan - and the expectation of its durability - fostered large capital outflows from Japan into highyielding markets until the eruption of the financial crisis in June 2007 and the consequent increase in asset prices volatility. The apparently durable profitability of such carry trade activities combined to a sustained depreciation of the Yen over protracted periods, has been a source of interrogation which only stopped when the financial crisis erupted and reversed the depreciation of the Yen. 
These events suggest that the initial success of monetary policy or exchange rate regimes like inflation targeting and currency pegs could have contributed to the development of large capital flows from one country to another. For example, the spreading of inflation targeting strategies across central banks in both developed and developing economies may have increased the recent intensity of carry trades. Indeed, if a central bank targeting inflation in a country with low interest rates does not lean against excess credit creation, the corresponding liquidity, if not used to finance local assets, may fund carry trades toward other higher inflation or higher expected return countries. This may reflect underdeveloped financial markets or the lack of equilibrating investment opportunities in the source country. If the recipient country is a credible inflation fighter, its bilateral exchange rate will tend to appreciate because the capital inflows will increase its asset prices. As a consequence, wealth effects will increase consumption growth while inflation remains subdued, at least for some time. In such occurrences, investors in the originating country will see their expectation of higher returns validated and may be encouraged to continue pouring capital into the high-yielding assets. This is probably the story one can tell for the developments observed from 2005 until mid 2007 between the Yen and the New Zealand and Australian dollar - as well as many Eastern European currencies $-{ }^{29}$ but this also characterises the dynamics of the euro/dollar exchange rate between 1999 and 2001.

Finally, past and more recent financial crisis episodes show a common element: the burst of the asset price bubble breaks down the optimistic and self-fulfilling investors' expectations and capital flows unravel. It is at this point in time, that many factors, including the nature of the actual investors - i.e. households, financial institution, pension and trust funds - or the positions taken on derivative markets by operators to cover and transfer risks affect the way the capital inflow reversal impacts economic developments and the transmission of monetary policy in both the country receiving and in the one originating capital flows. As apparent in the recent financial turmoil, the uncertainty about the identity of economic agents participating in the sharing of risk may also create a risk of liquidity in many markets. Hence, it is increasingly likely that asset price bubbles have an international impact and make it increasingly difficult to gauge in real time the location of such impact. Under such circumstances the time needed to identify such risks may be part of the crisis dynamics itself.

The burst of a bubble may not be the end of the story however, as the way this burst is managed by monetary and fiscal authorities may itself give rise to other bubbles. In the US case, the decision to keep interest rates low for a long period after 2001 may have encouraged the subsequent real estate bubble. In the Japanese case, one may argue that once the balance sheets of banks had been repaired, the lack of sufficient measures to curtail the growing size of the public debt has convinced Japanese private agents to search for higher returns abroad. Indeed, their substantial savings might have been accompanied by a

\footnotetext{
${ }^{29}$ For an exhaustive discussion of the recent and past carry trade episodes involving the yen, see Winters (2008).
} 
reluctance to invest in a country where the perspective of increasing tax rates is a natural consequence of the level of public debt. This also leads to delays in the increase of interest rates by a central bank concentrating on low forecasts of inflation, thereby encouraging and facilitating the development of carry trades.

\subsection{Globalisation and its reflection through monetary aggregates}

Overall, not only the faster transmission of shocks across asset classes and across countries but also the dynamics of asset price developments, of the associated flows of capital and of boom-bust movements need to be understood in order to explain the monetary and financial impact of globalisation, including global imbalances. This implies that beyond the real economy developments described in Sections 2 and 3 , monetary policy assessments now need to take into account the evolutions implied by the interplay of the four above-mentioned stylized facts. This is somewhat facilitated by making recourse to the concept of global liquidity. However, another useful approach is to develop the analysis of monetary aggregates and financial flows to complement usual economic analysis. Such consideration also helps take into account the specific phenomena underlying the successive developments of risk-taking and risk aversion attitudes among economic agents.

\subsubsection{Global liquidity may help reflect the impact of foreign originated shocks}

The globalisation of financial markets increases the importance of foreign developments in the domestic monetary policy transmission mechanism. In the three years before August 2007, the composition of cross-border capital flows has changed significantly from equity and foreign direct investments into more liquid assets, thus creating a sizeable amount of "global" liquidity that can move quite freely across financial markets. ${ }^{30}$ Consequently, one of the most debated issues at the level of world central banks at the moment is the implication of "global" liquidity for the conduct of monetary policy.

Research conducted at the $\mathrm{ECB}^{31}$ seems to suggest that global excess liquidity affects economic conditions in the euro area in a way that accords to the theoretical predictions, i.e. an expansion (contraction) of global excess liquidity increases (reduces) the inflationary pressures in the euro area. Furthermore, this research also shows that domestic liquidity conditions are important indicators for inflationary pressures in the other G7 economies. Hence, combining these results it could be argued that the research supports the argument that the euro area domestic inflation is affected by "global" inflation.

\footnotetext{
${ }^{30}$ Coincidentally, over the same period the daily correlation between changes in the ten-year swap rates in the United States and Germany has increased to 0.65 from less than 0.2 over the period 1990-2003 - see Bernanke (2007). The same picture emerges for the correlations between interest rate pairs with other $\mathrm{G} 7$ countries.

${ }^{31}$ Rüffer and Stracca (2006),
} 
This is a result that other authors obtain ${ }^{32}$ in different contexts and thus seems to be rather robust to modelling and methodological differences. However, domestic inflation always remains in the last analysis a phenomenon controllable by domestic monetary policy as explained in the next section. Hence, while useful to gauge global inflationary risks, it remains unclear whether and how such information can be used in the context of domestic monetary assessments.

Another "global" channel of transmission from liquidity conditions to inflation involves the overshooting of commodity prices following an expansion of money supply. Browne and Cronin (2007) use a cointegrating VAR model on US data to show that while both commodity and consumer prices are proportional to the money supply in the long run, commodity prices initially overshoot their new equilibrium values in response to a money supply shock, and the deviation of commodity prices from their equilibrium values has explanatory power for subsequent consumer price inflation changes. However, this approach does not take into account the money supply of other countries than the US or assumes that such supplies would be strongly correlated with the US data, which may be true over some periods but not for others.

Also, the concept of global liquidity, while helpful at global level does not reflect the tensions generated by cross-border flows, which it internalises. If it can be useful in order to understand global trends, possibly complementing the notion of 'global slack", for instance concerning commodity prices, it does not help to identify the individual roles of national or regional monetary policies. However, this increasing importance of capital flows creates practical difficulties for central bankers, be they pure inflation targeters or interested in monetary analysis and/or financial flows. In the first case, as argued before, the inclusion of asset prices, financial sectors, and capital flows in models of the economy would be highly desirable but it is not yet easy to achieve. In the case of central bankers also interested in monetary and/or financial flows analysis, international capital flows tend to make the link between money and prices unstable in the short to medium term, making the direct interpretation of monetary aggregates more difficult, but also more promising.

\subsubsection{The role of monetary analysis in identifying the impact of capital flows on price stability and asset prices.}

Monetary aggregates and their counterparts at the national or regional level, as they reflect international capital flows, may also be used to yield essential information on their impact and on the risks they create for the evolution of asset prices. The analysis of monetary aggregates and their counterparts, i.e. loans to the private sector and net external assets, allows the central bank not only to gauge medium to long term inflationary risks by correcting monetary aggregates from estimated portfolio shifts but also to form scenarios about plausible use of the corresponding liquidity. The identification of underlying trends

\footnotetext{
${ }^{32}$ Ciccarelli and Mojon (2005).
} 
combined to the estimation of the likely impact of the various scenarios concerning capital flows on the domestic economy allows to better measure the evolution of prices and of the associated risks. Thus, they are helpful to support a "risk management" approach to price stability by monetary authorities.

In this context, a direct approach for taking into account simultaneously asset price movements and inflationary pressures has recently been proposed. As shown by De Santis et al. (2008), asset prices in the US and the euro area interact with money in the euro area and influence the relationship between inflation and monetary aggregates. ${ }^{33}$ In particular, the interplay of the Tobin's $q$ in the two areas reflects well the shape of financial flows observed in the balance of payments of the euro area. Such inclusion of asset prices within money demand functions explains and deals with the instability of traditional money demand equations apparent after 2001 in the euro area. It also shows that the correction of monetary aggregates by the ECB staff to measure the underlying trend of money demand and called 'portfolio shifts' was justified. It demonstrates that money and asset prices both in the euro area and the US interact. Hence, monetary aggregates have the potential to help point at the risks created by asset price developments induced by capital flows.

For instance, the central bank will tend to interpret the moderate growth of both money and credit as a signal that money growth is likely to be driven by domestic money demand, thus posing fewer risks to price stability. Further, if money growth is low but credit dynamics are more buoyant, it is likely that net external assets of non-Monetary and Financial Institutions (MFI) are growing and that the domestic economy is financing investment abroad. In these circumstances, the central bank may have to form an opinion about the likely developments of the economies where domestic capital flows are directed. In case it views the foreign investment dynamics as led by an asset price bubble, it may warn investors and communicate its concerns. At the same time those capital outflows may signal a fundamental disequilibrium that may lie, for instance, in the domestic fiscal policy that is expected to constrain the evolution of inflation or in the level of national productivity and consequently in the external value of the domestic currency.

In other circumstances, it is money that grows fast while credit dynamics are subdued. In this case, money growth is led by the repatriation of foreign investments, whose proceedings are normally deposited with local financial institutions and result in an increase of domestic money. Typically these repatriation flows do not pose significant risks to price stability as they represent portfolio reallocation of wealth and they are unlikely to translate into excess demand. However, the central bank should monitor credit

\footnotetext{
${ }^{33}$ The policy regime choice in one country, thus, while in appearance justifiable as stability-oriented, in fact only transfers possible imbalances abroad through the financial channel and threatens the stability of the recipient country financial system.
} 
developments as the boost in domestic liquidity may lead financial institutions to relax credit conditions and eventually trigger an unsustainable loan binge.

The most complicated combination, however, may be the one where money and credit both grow quickly. In this case, capital flows do not matter much. The central bank must be able to assess if these developments are due to fundamental factors, like a more or less sustainable increase in productivity growth or, for instance a positive shock in real estate prices. In the first case, higher credit growth may be compatible with a higher desire of households to smooth their income over time. By borrowing more today, households increase the entire profile of their consumption path and they are able to do so because their expected real income is higher, due to the increase in productivity growth. In the second case, credit growth may be driven by the increase in household wealth eventually exacerbated by the characteristics of a domestic financial system that allows households to increase significantly their leverage. In these circumstances, central banks need to elaborate on possible scenarios and take into account the whole transmission mechanism, in order to properly assess the nature of the shock underlying the money and credit dynamics and also the eventual risks to price stability that those shocks would create.

What is rarely done however, due to the use of monetary analysis at national level rather than at international level, is to use it to better understand and perhaps identify the impact of national policies in initiating cross-border capital flows, leading to asset price movements abroad, and affecting global liquidity. Indeed, the bursting of an asset price bubble in one country, such as Japan, may have global consequences if the fight of its monetary authorities against subsequent deflationary trends thereafter leads to a durable facilitation of carry trades toward other zones. In particular, the deterioration of its fiscal position, if durable, may be seen as providing a guarantee that interest rates will remain low for a prolonged period and encourage outflows of an excess liquidity created to fight against deflation. This encourages inflows in economies offering higher interest rates, for instance if their peg to another major currency guarantees high rates with limited foreign exchange risk in a period of low global volatility. In a similar way, the burst of the high tech bubble in the US led to substantial capital inflows in the euro area and to money hoarding, explaining substantial growth rates of monetary aggregates without corresponding price pressures.

4.3.3 The emergence of new financial market products and players and the "behavioural" or "risk taking" channel of monetary policy.

The emergence of new categories of investors and financial intermediaries, whose behaviour and incentives ${ }^{34}$ may be quite different from the traditional categories of market players - like the banks -, has probably modified the way shocks propagate across financial markets and monetary policy impulses are

\footnotetext{
${ }^{34}$ Rajan (2006).
} 
transmitted to the rest of the economy. The same is true with the generalisation of the credit derivatives use which, due to their "off the balance sheet" status, often makes the international propagation of their effects difficult to follow.

First of all, the proliferation of financial intermediaries whose main value added is in securitising and making liquid - i.e. tradable in the market place - assets that until few years ago would have been highly illiquid and remained on the originators' balance sheet has increased the ability of the financial system to multiply liquidity. To be sure, this is by no means a problematic development per se, but rather one of the desirable outcomes that macroeconomic stability - which mostly has to be ascribed to the increased quality of monetary and fiscal policy in many countries over the last 25 years - is supposed to deliver. In a stable macroeconomic environment that is vastly less risky and friendlier to businesses than it used to be in the not-so-distant past, higher expected profits - and lower risks around those profit expectations ought to induce greater risk-taking, and low short-term volatility to encourage the creation of market liquidity by financial institutions. Figure VI below, draws from balance sheet data of both the US financial and non-financial corporate sectors to show how both sectors of the US economy manage actively their own balance sheet. ${ }^{35}$ Security dealers and brokers - which include the once well-known large US investment banks -, in particular, tend to create liquidity during periods of asset price booms and drain liquidity during periods of asset prices declines. Such behaviour tends to impart "bubbly" dynamics on asset prices thus feeding its own collapse. The beneficial effects of "liquefying" specific assets, like mortgage loans, become sclerotic once the unsustainable dynamics in the price of the underlying assets which in this case are the house prices - reverts, financial institutions engage in massive de-leveraging and cause a drainage of market of market liquidity which hits the global financial system at its heart.

\section{Insert Figure VI here.}

Furthermore, behavioural shifts have occurred - like they always did on occasion of past episodes of asset price bubbles - that are associated with new products and increased incentives of financial markets' players to pursue risky investment strategies. Risk shifting, illiquidity seeking, tail risk seeking and, of course, herding, ${ }^{36}$ may affect the way central banks influence the economy through the conventional channels of transmission. In other words the classic channels - interest rate, balance sheet, bank lending and liquidity channels - might be affected in such a way as to influence the effectiveness of monetary policy to an extent that was unknown before. This is what some authors prefer to introduce as a

\footnotetext{
${ }^{35}$ That is to say that leverage is prociclycal. When asset prices increases, the equity capital of the firm increases, thus reducing its leverage, which is defines as the ratio of assets over equity. If firms tend to target a constant, or even increasing, leverage ratio they must take up new debt and purchase new assets.

${ }^{36}$ Rajan (2006a)
} 
supplementary channel which they call a "behavioural" or "risk taking" channel for the transmission of monetary policy.

In an era when banks dominated financial systems, incentives on bank officials were clear. Their salary would rarely depend on short term banks' investment returns and they thus had little interest in seeking extra returns that, being more risky, could have jeopardised banks' balance sheet. Shareholders on their side were happy to enjoy the steady rent arising from the limited competition in the market for funds and the system was able to deliver a stable but inefficiently conservative financial intermediation flows. In the modern, deregulated and competitive environment, investment managers in investment banks or in other financial intermediaries have at least up to now worked with an incentive structure commensurate to the new context.. As the penalty of bad investment performance in the new environment was believed to be less drastic than a bank run, investment managers may have perceived that there is more upside than downside to adding risk in order to generate extra returns immediately affecting their own salaries. In such an environment, what really mattered for many investment managers was to perform better then their peers, or at least, not worse. And this generates two perverse consequences. ${ }^{37}$ First, investment managers try to boost returns by investing in assets that have risk characteristics easily concealed from investors, namely that perform extremely badly in case of extreme events but offered generous returns in the rest of the time. The finance literature calls these risk "tail risks". The second perverse consequence is the incentive for investment managers to herd with competitor managers, because this behaviour provides them with the insurance that they will not underperform their peers. It is easy to appreciate how both behaviours tend to reinforce each other in periods of asset prices increases that provide the impetus for an upward spiral, which feeds itself and is prone to develop into a credit bubble.

The combination of financial innovation and behavioural shifts of market participants increases the vulnerability of the international financial system to sudden gyrations in markets' risk perceptions and tolerance. The explosive dynamics imparted by the ability of financial institutions to pack and sell risk to credit growth becomes an equally powerful implosive force when risky events materialise and hit financial institutions' balance sheets. Furthermore, if the losses are realised on off-balance sheet positions, by definition there is no market that can offer actual prices due to the absence of market makers and clearing houses. In such context, liquidity crises can easily erupt as most participants have difficulty assessing both the soundness of their own balance sheets and those of their counterparties.

One clear example of such perverse dynamics is the ongoing financial turmoil that originated in the US sub-prime mortgage market. Over the period 2002-2005 the combination of rising house prices and very low interest rates contributed to increase both households' demand for mortgage credit and the risk appetite of financial institutions in search of higher returns. Thanks to financial innovation, primary

\footnotetext{
${ }^{37}$ Rajan (2006).
} 
mortgage lenders securitised their loans thus in practice separating out their lending business from the risks implied by holding mortgage loans on their own balance sheets. Through mortgage backed derivatives mortgage lenders could lock in their return on the mortgage while the buyers of the mortgage risks, mostly hedge funds and non-bank institutions, would obtain the extra-return they were seeking. In the absence of market players with a higher tolerance for risk, these dynamics would not have developed. In normal times, these are beneficial dynamics because they help allocate capital more efficiently to those agents that can bear particular risk/return profiles of their investments and result in a higher provision of funds to those who may need it.

However, after a significant decline of house prices and the tightening of monetary policy that started in 2006, the defaults on mortgage loans and home foreclosures in the US increased, until the market for mortgage backed securities came to a sudden standstill in August 2007. Credit and liquidity risk worldwide increased sharply and the turmoil spread very quickly from the US into global financial markets and from mortgage markets to other asset classes including money markets. In these circumstances, financial institutions around the globe could not sell the risk in the market anymore and were forced to retain on their balance sheet a significant amount of non-performing mortgage loans. Hence, such financial institutions had to cut their exposures to other investments in order to repair their balance sheets and the global credit flows dried up sharply.

These developments show that in some circumstances the presence of high risk investors with relatively short term investment horizon can instil perverse dynamics and foster asset price bubbles eventually leading to an increase of leverage in the economy much above a sustainable level. Beyond logical considerations concerning the reforms of the regulatory framework that should be aimed at avoiding exante any unsustainable credit creation dynamics, the changes in the financial markets' microstructure and their ability to engineer and supply more innovative and complicated products thus have a few important implications for monetary policy.

First, central banks have to make sure to avoid the risk of becoming, paradoxically, victims of their own success in achieving macroeconomic stability and earning high credibility. Periods of macroeconomic low volatility may well be those periods when market dynamics "take a life of their own" and depart from any rational considerations of possible risks. This implies that central banks have a duty to base their analysis, recommendation and policy decisions on a firm focus on fundamental trends in the economy.. In particular, central banks should be very cautious when communicating to the markets and the public in general in order to avoid fostering unsustainable expectations among market participants. In some circumstances, the unfounded expectations of a certain future policy course may have amplifying effect on asset prices and thus may contribute to the build-up of those financial imbalances which would quickly and costly unwind once expectations change. 
Third, central banks should devote maximum effort to understanding the extent to which the transmission channel of monetary policy in a stable macroeconomic environment may be affected by both a high degree of integration of global financial markets and an ever developing market microstructure. For example, globalisation and the perverse behaviours spurred by financial innovation may have combined in the last two years to make the long end of the yield curve less responsive to the monetary policy tightening - especially in the United States, but also in the euro area - than it was expected to be on the basis of historical experience. It is very likely, in fact, that global savings were flowing into the United States attracted by the unsustainable low risk-return profile offered by new financial products and from the mirage that the credit risk premium had almost disappeared.

Fourth, central banks need liquidity policies well adapted to the occurrence and development across time of deep financial scares. Ex-ante, a liquidity management framework that allows a wide range of high quality collateral and a large number of possible counterparties is helpful in maintaining market access of illiquid but solvent institutions. Moreover, international co-operation in order to allow the dispersion of liquidity in foreign currencies across domestic banks is also needed.

However, this may not be sufficient. Latest developments show that at times, drastic decisions - like the acceptance of lower-rates collaterals and state guarantees of interbank operations - may be needed to reignite markets. Such decisions, which de facto expand the role of monetary policy and threaten to reduce the efficiency of financial markets, also increase the risks and the potential fiscal costs borne by the authorities. This begs the question whether it would not be desirable to include in the central banks' operational framework the possibility to pursue extraordinary liquidity strategies beyond those aimed at very short term money markets in order to avoid recurring to such extreme initiatives. For instance, it is possible to imagine a catalytic role for central banks - including moral suasion - in re-organising the market infrastructure and/or maintaining the trading activity in some high quality assets, that are used by banks as collateral in their repo operations when trading in low quality assets is shunned by the financial system. Further, in some circumstances it may be possible - and even profitable - for central banks to sell treasury bills against assets of high quality in order to foster the appreciation of the latter. Such operation might be profitable for central banks and simultaneously may diminish the number of banks having to post losses on their trading books. Such exceptional provision should be designed in a way that clarifies the instances in which they can be applied and the expected exit strategy, in order to minimise moral hazard and inefficient intervention in money markets. It is probably fair to admit that the lack of such contingency provisions in the central banks liquidity management framework has deprived monetary authorities of possible weapons to foster the unwinding of the financial turmoil which transformed later into a financial crisis. In many circumstances, banks with sufficient amounts of capital from the viewpoint of their Tier1 ratios became illiquid first and insolvent thereafter due to the fall in the value of highquality but not anymore traded assets. It may thus be argued that some support of financial prices by 
central banks could have avoided the almost complete blocking of transactions and might have even avoided the recourse to injections of capital.

Lastly, it may be important to increase the exchange of information between central bankers and supervisors as well as the ability of statisticians to follow the development of "off balance sheet" positions of financial intermediaries. Also, it may be useful to create incentives for financial institutions to create and trade in standardised and exchange-traded securities in order to increase transparency and reduce systemic risk. ${ }^{38}$ Standardised securities are normally traded through clearing houses that ensure that every party to a financial contract meets its own obligation. Furthermore, clearing houses mark to market continuously gains and losses and impose on the parties of the contract margin requirements that depend on valuation changes. Hence, margin requirements serve the role of capital requirements for banks and marking to markets allows to monitor in a transparent way the state of each financial market' capital. In the end, counterparty and liquidity risk is easier to quantify in real time and the likelihood that credit bubbles - eventually involving the creation of obscure financial securities that are not easily detectable in the balance sheet of financial institutions - develop is much lower.

\section{The implications of globalisation for monetary policy}

The recent developments in inflation both in the industrialised and the emerging economies and the propagation of the financial tensions in the US suggest that globalisation may now be entering into a new stage. Following a period when the opening of international commodities and service markets to the emerging markets caused the relative price of manufactured goods - and some services - to decline worldwide, the ongoing growth of such markets is now contributing to the current upward pressure on the price of food and on raw materials that are employed into their manufacturing sectors. In fact, the net effect in industrialised countries is the, sometimes significant, ongoing acceleration in domestic inflation. Simultaneously, the increase of financial pressures evidenced by the ongoing deepening of the financial turmoil makes clear that globalisation carries also with it the risk of fast transmission of financial pressures.

Globalisation, which initially seemed characterised by its downward impact on prices and inflation, is now increasingly recognised as a complex factor with multiple influences. While its potential for generating upward pressures on inflation is fully recognised, its other effects including the rapid transmission of financial shocks are also apparent. This has generated interrogations of many types: has the ability of national central banks to control inflation at national level been impaired? Conversely, can

\footnotetext{
${ }^{38}$ Cecchetti (2007).
} 
the propagation of financial scares be controlled or prevented? In particular, which techniques should be adopted or developed by central bankers to facilitate such control? Beyond macroeconomic considerations, how to manage money market liquidity in the context of an international financial turmoil? More generally, which role to give to international co-operation in such fields? This section first considers the impact of globalisation on the case for domestically conducted monetary policies and considers the evolution of techniques used by central bankers in the macroeconomic field. It then deals with the challenges brought by financial innovation and integration. Finally, it deals with the need for an enhanced international co-ordination.

\subsection{Globalization and monetary policy: the case for a domestically conducted monetary policy}

Globalisation does not weaken the case for a domestically conducted monetary policy aiming at price stability over the medium term. In cases of capital and/or goods markets integration, higher openness does not impair the ability of domestic monetary policy to control inflation. Inflation is always in the end a monetary phenomenon, i.e. a phenomenon that the central bank can control. In a recent contribution, Woodford (2007) uses an open-economy structural model to make that point, i.e. that neither a high degree of financial markets integration ${ }^{39}$ nor a higher role of a "global" measure of economic activity slack on the dynamics of domestic supply are likely to weaken the ability of national central banks to control the dynamics of domestic inflation. In the same vein, Taylor (2008) argues that there exist clear evidence based on various models that monetary policy co-operation does not deliver additional gains as compared to domestic monetary policy. Thus, he concludes that in the most efficient monetary policy framework, central banks may act on their own to the extent they incorporate in their decisions the expected actions of the other central banks. In such framework, it is crucial that monetary policy authorities exchange information so that each of them can incorporate the others' monetary policy reaction into its own decisions.

However, globalisation has brought some significant challenges and requires new aspects of monetary policy to be investigated in order to ensure the maintenance of price stability. In Rogoff (2006) words', globalisation, through both goods and asset price arbitrage, "is weakening the grip of individual central banks over the trajectory of domestic real interest rates, except at relatively short horizons". Moreover, recent developments such as the GSEs crises and the bankruptcy of several investment banks in the US make clear that propagation risks have enormously increased. Hence, the monetary policy implications of the changes in the transmission mechanism engineered by both the structural changes described in Sections 2 and 3 and the four stylised facts discussed in Section 4 have to be drawn.

\footnotetext{
${ }^{39}$ Financial integration in Woodford's analysis is captured by allowing global liquidity to be the determinant of the domestic interest rate and allowing the global saving-investment balance to determine the domestic equilibrium real interest rate.
} 


\subsection{Globalisation and monetary policy: facing the challenges of structural changes}

The first implication of the changes in the transmission mechanism of monetary policy due to globalisation is the need for central banks to go beyond simple models and widen the battery of tools used to gauge inflationary pressures, including structural analysis into the assessment process. Structural analysis, in conjunction with other models and indicators, can be very useful in identifying possible shocks hitting the economy but also in devising the right response to them.

First, simple rules and concepts like "output gap" or "core inflation" are increasingly insufficient as explained in section 2. As a consequence, a more sophisticated analysis is necessary. Second, a structural understanding of global shocks is increasingly needed: therefore, DSGE models are increasingly useful, especially is they have adjustable production functions and have adjustable exchange rate pass-through. The actual flexibility of various markets needs to be taken into account as well as the impact of international competition on the length of needed adjustments and hence on the shape of the business cycle. Third, the impact of globalisation on inflation perceptions and the credibility of the central bank should not be forgotten. In particular, it is now necessary for central bankers to take into account the risk of second round effects and of a dispersion of inflation expectations in order to ensure that economic agents concentrate on the adequate response to the challenges faced. Hence, credibility, inflationary perceptions should be measured and if possible modelled. Finally, for this reason, communication, transparency and competence are increasingly pivotal for central banks. It is in particular important for them to convince fiscal authorities to avoid any measure which would amplify inflation or delay the economic adjustment.

\subsection{Globalisation and monetary policy: facing the challenges of financial integration}

Facing the challenges of financial integration implies even further adjustment in the behaviour of central banks. First, they need to acknowledge that asset prices developments lead more often than usually expected to abrupt asset price developments. The frequency of fat-tail events is not consistent with usual Gaussian distributions. Second, they need to learn how to monitor the flows of liquidity which help propagate the development asset price bubbles and are often underlying the development of global imbalances. This is complicated by the fact that capital flows may encourage asset price movements across borders and that money may shift from one type of asset to another when liquidity allows it. . Third, central banks need to learn how to efficiently "lean against the wind". It is now apparent that asymmetric central bank responses such as the ones advocated by A. Greenspan, end up encouraging moral hazard and are finally counter-productive. Indeed, an effective risk management attitude must also be forward looking. The size, the duration, as well as the contagious nature of the current financial 
turmoil strongly support this point which also finds some support at theoretical level. Indeed, Loisel et al. (2007) in a closed economy context show that there exist particular situations where a central bank can usefully lean against the wind. These cases are characterised by asset price bubbles that develop due to herding behaviour of entrepreneurs that take investment decisions based on other entrepreneurs' decisions rather than on fundamental signals arising from the economy. By increasing the cost of borrowing on the basis of the observed herding behaviour, the central bank can curb the investment of herding entrepreneurs, which is in this case very sensitive to the cost of borrowing, and thus reduce the risk of asset price bubbles. Those entrepreneurs who actually invest based on fundamental rationale will be only marginally hit, given that the expected return from the investment is, for these entrepreneurs, not equal to the borrowing cost.

This is not to say that the identification of asset price bubbles does not remain difficult. Nor does it imply that central banks may be able to always influence asset prices. Nor does it imply that central banks should 'prick asset price bubbles'. Irrational exuberance is indeed a reality. Also, targeting asset prices directly would even more directly encourage moral hazard than asymmetrical behaviours. Rather, central banks should develop a broad range of models and indicators in order to ensure that the fundamental analysis of asset prices developments is as robust as possible. The generalised persistence of unexplained paths for the residuals across statistical and econometric models and the eventual instability in their parameters may well flash a warning light that a bubble is in the making.

The recent financial crisis is one case in point, as the excessive decrease of risk premia up to 2007 was for many a clear sign of asset price disequilibria and excess liquidity. ${ }^{40}$

In this context, as discussed in Section 4.2.2, the recent turmoil suggests that due to financial globalisation central banks should devote more resources to the analysis of global capital flows and to their impact on the developments of domestic saving-investment balance and current accounts across economic areas, which may prove to be not sustainable. This also pleads for an increasing inclusion of financial frictions in DSGE models, and in particular of both a non-financial sector and a banking sector.

Moreover, monitoring and analysing monetary aggregates with a view to identifying underlying trends also leads to identifying the more volatile impact of asset prices on such aggregates. This systematic monitoring naturally leads to constructing "risk scenarios" concerning the likely developments in some part of the economy or of financial markets. In this way the policymaker can assess the relative probabilities of a larger number of uncertain future developments and, thus, make a more robust assessment of its own monetary policy stance.

\footnotetext{
${ }^{40}$ See the Overview of ECB (2007), pp. 9-15.
} 
Hence, central banks should consider the possibility to adjust their monetary policy stance in response to excessive asset price movements, when there is a high probability that capital flows and credit dynamics are driven by self-fulfilling expectations of continuously increasing asset prices or unrealistic expectations about the developments in fundamentals. The cost of inaction, in some cases, may be much higher than the negative wealth effects of burst bubbles and may lead to periods of heightened financial and possibly also economic- instability. It is important however that such action is not perceived as targeting asset prices. In fact, its goal should be to avoid increasing disequilibria of such prices rather than supporting them at any equilibrium level. A good candidate strategy for such purpose is the two-pillar strategy used by the ECB. As monetary and credit aggregates often reflect the risks of bubbles in the economy without being associated with specific asset markets, it allows the central banker to avoid the moral hazard connected to 'leaning against the wind'. ${ }^{41}$

The higher role of international financial transactions in the transmission mechanism of monetary policy requires however that monetary policy authorities gain more insight and expertise in the analysis of financial market microstructure, including the functioning of continuously new and more complicated financial products. The analysis of monetary aggregates and their counterparts with a view to gauge the medium-to long term risks to price stability can help to detect possible bubbly developments in asset markets if a detailed knowledge of the financial micro-structure and of financial products is available to the central bank.

Hence, available assessments of the stability of the domestic and the international financial system should be routinely taken into account in the assessment of the monetary policy stance and the risks to price stability. By considering financial stability issues only in financial stability reports, central bankers may miss important elements in their evaluation and risk being caught by surprise by the unwinding of asset market bubbles. The latter may be fostered by the same low volatility environment that the central bank has contributed to establish - and by, in particular, the possibly persistent changes in the size and quality of international capital flows. Furthermore, the decline in the investors' "home bias" exposes any economy to the possibility that the benefits of asset diversification - in terms of low volatility of output and inflation - may abruptly evaporate and sharp asset price changes in international asset prices may lead to severe income and wealth losses in the domestic economy. In this respect, central banks and supervisory authorities should co-operate in order to provide monetary authorities with a thorough

\footnotetext{
${ }^{41}$ Ultimately, this approach would not differ in substance from the approach that central banks already adopt when exchange rate dynamics depart from their estimated "fundamental "value. In normal times, the central banks of large economic areas do not intervene in the foreign exchange markets to avoid creating conflicts with their primary objective of domestic price stability. However, occasionally these central banks may find it optimal to intervene in a co-ordinated manner with a view to "throw sand in the wheels" of speculators, once their internal analyses show that actual exchange rate developments are not compatible with any of the models that are supposed to explain exchange rate behaviour.
} 
analysis of the risks embedded in the financial system, which is constantly evolving both in terms of products and of characteristics of its players.

Finally, the current financial turmoil shows that a high degree of consistency between central banks operational frameworks, the organisation at national level of the function of lender of last resort, and the responsibility of the central bank for financial stability is needed.

An important lesson for central banks taught by the recent financial turmoil concerns the need to avoid that in periods of heightened volatility the increase in risk premia not only affects the markets in longer dated securities but also puts money markets under stress. The collapse in the US mortgage market has put into question the ability of financial institutions to engineer financial products that actually transform previously illiquid assets - i.e. mortgages - into easily tradable instruments. When the mortgage market crisis erupted in June 2007, the liquidity flows suddenly dried up and what started as a problem in a quite limited segment of the world financial markets quickly spilled over into other markets, including the one for very short term securities. Thus, it became an urgent issue for central banks to avoid that credit and liquidity risks would compound and bring the international financial markets to the verge of the collapse. Since June 2007, the major central banks of the world have engaged in "extraordinary" liquidity injections, which allowed money markets to recover their functioning. On this occurrence, the ECB operational framework that allows a wide range of collateral and a high number of institutions to participate to its refinancing auctions proved to be very useful in absorbing the sudden increase in risk premia and restore the orderly functioning of money markets.

Hence, it is preferable to avail an operational framework that allows the central bank to lend to all solvent counterparties against high quality collateral rather than to a limited set of counterparties. This allows to clearly differentiating between operations which do not carry financial risk for the central bank and operations which carry such risk. If collateral of low quality needs to be accepted from a counterparty judged solvent, such operation can effectively be called emergency liquidity activity and be undertaken under the responsibility of the central bank. Moreover, it is important that to, in the central bank statute or in an explicit and formal agreement with fiscal authorities, the cost of eventual financial losses created by insolvent counterparties is fully born by those financial institutions themselves. In a context in which large banks may turn insolvent, this ensures the independence of the central bank and the soundness of its balance sheet. For the ECB and the Eurosystem, this is ensured by the article 101 of the Treaty which forbids the direct financing or subsidisation of other European institutions by the Eurosystem. Finally, this overall organisation including the 'leaning against the wind' part is consistent with a system where a central bank contributes to financial stability rather than is fully responsible for it. ${ }^{42}$

\footnotetext{
${ }^{42}$ See Bini-Smaghi (2008), Uhlig, (2008) and Goodfriend (2008).
} 


\subsection{Globalisation and international policy co-operation ${ }^{43}$}

The higher integration of financial markets and the role of new countries in the global exchange of capital challenge also international fora to strive for better analysis and understanding of the ongoing changes in the international financial system. Since the 1980s, many systemic crises have occurred that had different explanations and developed in different ways. Each of these crises episodes led international institutions to learn from their mistakes and implement monitoring and cooperation frameworks that would have reduced the risks of a similar crisis. The G7 has been instrumental in shaping the international financial architecture as it reacted to the need to better involve emerging market economies. In particular, since the creation of the Group of Twenty (G20) forum of finance ministers and central bank governors in 1999, emerging market countries have been involved in global economic and financial stability issues like exchange rate regimes, prudent debt management, domestic financial deepening and international codes and standards. The G20 has also played an important role in forging consensus on reforms of the Bretton Woods institutions and has been constructively involved in helping shape mechanisms of crisis prevention and resolution.

However, the development and the integration of global financial markets pose new challenges to policymakers and suggest that international co-operation need to take new forms in order to address such challenges. The Multilateral Consultation procedures inaugurated and sponsored by the IMF in 2006 - on Global Imbalances - may prove to be the right forum for his purpose, under the condition that the analysis is broadened in order to fully incorporate the interrelated dynamics of global financial markets. In particular, the Multilateral Consultation procedure should take a global perspective and assess the risk to monetary and financial stability by taking into account both the possible existence, assessment and the prospective impact of asset price disequilibria and their international channels of transmission. For example, phenomena like global imbalances or carry trade financial flows as discussed in Section 4.2.2 should be analysed from a multilateral point of view because the eventual domestic policy misalignments or the possible developments of an asset price bubble can easily have a significant repercussion on the risks to price and financial stability in other parts of the world. In particular, a multilateral exercise that focuses also on capital flows and their nature could help assessing asset price developments and eventually help central banks to set monetary policy in a manner that incorporates the risk of a bubble building up and eventually bursting in the medium term. Such "leaning against the wind" would not aim at pricking the bubble but rather at avoiding a monetary policy stance that passively contribute - also by facilitating credit growth - to the inflating of the bubble. Hence, it is relevant to examine whether excess liquidity flows in an open economy context may not also spur asset price bubbles.

\footnotetext{
${ }^{43}$ Here, international "co-operation" indicates a more or less formal framework which facilitates the exchange of information among policymakers and the sharing of views about the nature and the consequences of particular international policy considerations. The term "co-operation" does not signify any act of various policy authorities that would imply a common decision to have an immediate consequence on their respective policy instrument
} 
Finally, a better cooperation in terms of liquidity provision is also needed. A first example of successful cooperation comes from the auctions of US dollar liquidity jointly organised by the Federal Reserve, the ECB and the BNS since the start of the turmoil in mid-2007. Its generalisation might be envisaged to deal with other crises in the future. Moreover, international institutions must better understand the dynamics of liquidity crises and be able to advice countries on their best strategies. Furthermore, it may be wondered how to optimally organise the participation of countries to such cooperation. Who might join such cooperation and how to monitor the risks to those countries who do not participate? Lastly, how to make compatible the corresponding swap agreements and the various other facilities made available by regional or international institutions?

\section{Conclusion}

Globalisation is a dynamic, multi-faceted, phenomenon that changes the structure of the national economies and the way shocks propagates both within a single economy and across the world. In particular, the emergence of large countries participating to the global markets for good, services and financial assets is likely to affect inflation developments in new ways that are, to some extent, unexplored by central banks. This paper argues that the challenges posed by globalisation do not call for a higher "coordination" of monetary policies across the world. National monetary policies, which are oriented towards the maintenance of domestic price stability, are still the most efficient solution to control inflation developments and, consequently, contribute to financial stability.

Nevertheless, globalisation has probably contributed to stir some major evolution in the way central banks ought to perform their duties. The possibility of changes in the economic relationships driving output growth and price formation mechanisms and the multiplication of external shocks, of different nature, that can hit the domestic economy suggests that central banks should devote more effort in structural analysis then they were used in the past. A robust, "risk-managing" approach to monetary policy must be able to identify as precisely as possible the shocks, the way they are transmitted to the domestic economy and, ultimately, how they can affect domestic inflation.

In particular, central banks must take into account how the evolution of financial markets' structure and their increased interdependence may play out in the transmission mechanism of monetary policy. Liberal and innovative capital markets may have a non-negligible role in the creation of liquidity, which is not always and necessarily aligned with the central banks' objective of price stability. In this respect, the ongoing financial crisis has demonstrated that financial stability considerations are not always separable from the analysis of the risks to price stability, but rather should be part of the normal assessment of the monetary policy stance. As a consequence, it is conceivable that central banks may, under certain conditions that are admittedly very difficult to be met in reality, use monetary policy to "lean against the 
wind" of possible asset price bubbles, if the eventual bust is judged to pose significant risks to price stability. In this case, the high uncertainty surrounding the existence of a bubble in a certain asset market should be weighted against the eventual costs of the burst and without ruling out "tail" events. The analysis of monetary and credit aggregates can provide valuable information to the identification of the risks of a bubble bursting.

Finally, the increased interdependence of financial markets across the world and the possible impact that financial flows can have on the global economy suggest that the multilateral policy co-operation must take new forms. In particular, the already existing surveillance framework should be enlarged in order to encompass a thorough analysis of domestic and international capital markets, including the possible role that domestic monetary policies may have on capital flows and on the liquidity conditions in each country.

\section{References}

Adrian, T and H. S. Shin (2008), "Liquidity and leverage”, FRB New York Staff Report No. 328 (May), Federal reserve Bank New York

Anderton, Robert (2007), "Globalisation, exchange rate pass-through and trade impacts: a euro area perspective", presented at the International Monetary Seminar on "Globalisation, inflation and financial markets", Paris 11-15 June.

Batini, N., B. Jackson and S. Nickell (2005), “An open economy New Keynesian Phillips curve for the UK”, Journal of Monetary Economics, vol. 52, pp. 1061-1071.

Bayoumi, T and A. Swinston (2007), "The ties that bind: measuring international bond spillovers using inflation-indexed bond yields", IMF Working Paper N.128, June

Bean, C. "Globalisation and inflation", presentation to the LSE Economic Society, 24 October 2006.

Benati, L. (2007), “The time-varying Phillips correlation”, Journal of Money, Credit and Banking, Vol. 39 No. 5, pp 1275-1283. 
Bernanke, B. S. (2007), "Globalisation and monetary policy", Remarks at the Fourth Economic Summit, Stanford Institute for Economic policy Research, Stanford, California. March.

Bini-Smaghi, L. (2008), intervention on "Solvency, systemic risk and moral hazard: where does he central bank's role begin and where does it end?" held at the conference "The ECB and its Watchers X" hosted by the CFS and Goethe University Frankfurt, 5 September, Frankfurt.

Blanchard, J. O. and J. Gali, (2007), "The macroeconomic effects of oil price shocks: why are the 2000s so different from the 1970s?", NBER Working Paper Series, WP No. 13368 (September).

Blanchard, O.and J. Simon (2001). "The Long and Large Decline in U.S. Output Volatility," Brookings Papers on Economic Activity, 1, pp. 135-64;

Borio, C. and A. Filardo (2007), "Globalisation and inflation: New cross-country evidence on the global determinants of domestic inflation”, BIS Working Papers No. 227, May.

Brender, A. and F. Pisani (2007) Global imbalances. Is t he world economy really at risk?, Dexia SA, Belgium

British Bankers Association (2006), Credit Derivatives Report.

Browne, F and D. Cronin (2007), "Commodity prices, money and inflation", ECB Working Paper No. 738. March.

Calza, A. (2008), "Globalisation, domestic inflation and global output gaps: Evidence from the euro area". ECB Working Papers No. 890. April.

Cecchetti, S. (2007), “A better way to organise securities markets”, Financial Times, 4 October

Ciccareli, M. and B. Mojon (2005), "Global Inflation", ECB Working Paper No. 537, October. Forthcoming in Review of Economic Studies.

Christiano, L., C. Ilut, R. Motto and M. Rostagno (2008), "Monetary policy and stock market boom-bust cycles”, ECB Working Papers No. 955. October.

De Santis, R., C. A. Favero and B. Roffia (2008), "Euro area money demand and international portfolio allocation: a contribution to assessing risks to price stability", ECB Working Paper No. 926. August.

ECB (2006) "Effects of the rising trade integration of low-cost countries on euro area import prices", ECB Monthly Bulletin August 2006, box 6, 56-57;

ECB (2007), Financial Stability Review, European Central Bank, June. Frankfurt,

Ehrmann, M. and M. Fratzscher (2006), "Global Financial transmission of monetary policy shocks", $E C B$ Working Paper No. 616. April.

Ehrmann, M., M. Fratzscher, and R. Rigobon (2005), "Stocks, Bonds, Money Markets, and Exchange Rates: Measuring International Financial Transmission”, NBER Working Paper No.11166, March.

European Securitazion Forum (2008), ESF Securitazion Data Report - 1Q:2008. 
Gali, J and T. Monacelli (2005), "Monetary Policy and Exchange Rate Volatility in a Small Open Economy, Review of Economic Studies 72 (3), 707-734.

Goodfriend, M. (2008), intervention on "Monetary policy during the financial turmoil: what have we learned?" held at the conference "The ECB and its Watchers X" hosted by the CFS and Goethe University Frankfurt, 5 September, Frankfurt.

Greenspan, A. (2003), "Global finance: is it slowing?" Speech delivered (via satellite) at the International Symposium on "Monetary Policy, Economic Cycle, and Financial Dynamics" hosted by the Banque de France, March. Paris,

Grubel, H. G. (1968), "Internationally Diversified Portfolios," American Economic Review, Vol. 58, pp. 1299-314

Ihrig, J., S. B Kamin,. D. Lindner and J. Marquez (2007), "Some Simple Tests of the Globalization and Inflation Hypothesis", International Finance Discussion Papers No. 891, April. Federal Reserve Board.

IMF (2007), Annual Report on exchange agreement and exchange restrictions., Washington D. C.

IMF (2006), "How has globalisation affected inflation" in World economic Outlook (Chapt. III), pp. 97134, April, Washington D. C.

International Swap and Derivatives Association (2008), Summaries of market survey results, 1H2008 (at http://www.isda.org/).

Lane, P. R. and G. M. Milesi-Ferretti (2008), "The drivers of financial globalisation", American Economic Review, Vol. 98 (2), pp. 327-332.

Lane, P. R. and G. M. Milesi-Ferretti (2007), "The external wealth of nations mark II: Revised and extended estimates of foreign assets and liabilities, 1970-2004", Journal of International Economics, Vol. 73 (2), November, pp. 223-250.

Loisel, O., A. Pommeret and F. Portier (2007), "Monetary policy and herd behaviour in new-tech investment", paper presented at the conference "Banking and asset markets: developments, risks and policy issues", hosted by CEPR-Fondation Banque de France, 29-30 November, Paris.

Markowitz, H. (1952), "Portfolio Selection,", Journal of Finance, vol. 7 (1), pp. 77-91.

McConnell, M. and G. Perez-Quiros (2000). "Output Fluctuations in the United States: What Has Changed since the Early 1980s?" American Economic Review, 90, pp. 1464-76.

OECD-FAO (2008), Agricultural Outlook 2008-2017, OECD/FAO.

Pain, N, I. Koske and M. Sollie (2006), "Globalisation and inflation in the OECD economies", OECD Economics Department Working Papers, No. 524 (November).

Pétursson, T. G. (2000), “Exchange rate or inflation targeting in monetary policy?", in Monetary Bulletin, Central Bank of Iceland, Vol. 2 (1), February, pp. 36-45. 
Pétursson, T. G. (2004), "Formulation of inflation targeting around the world", in Monetary Bulletin, Central Bank of Iceland, Vol. 6 (1). March, pp. 57-84

Poloni, P. and J. Reynaud (2008), "How to measure credit risk transfer in the EU", paper presented at the Fourth IFC Conference on Measuring Financial Innovation and Its Impact, Basel, 26-27 August.

Pula, G. and F. Skudelny (2007) "The impact of rising imports from low-cost countries on Euro Area prices and labour markets - some preliminary findings", paper presented at the conference on "Globalisation and the macroeconomy", hosted by the European central Bank , 23-24 July 2007, Frankfurt..

Rajan, R. G. (2006), "Has Finance Made the World Riskier?", European Financial Management, Vol. 12 (4), pp. 499-533.

Rajan, R. G. (2006a), "Monetary Policy and Incentives", address at the conference on "Central Banks in the 21st Century" hosted by the Central Bank of Spain, 8 June 2006, Madrid.

Rogoff, K. (2006), "Impact of globalisation on monetary policy", paper presented at the Symposium on "The New economic Geography: Effects and Policy Implications", Jackson Hole, August.

Rogoff, K.J. (2003), "Globalisation and global disinflation", in Federal Reserve of Kansas City, Monetary Policy and Uncertainty: Adapting to a Changing Economy, pp. 77-112.

Rüffer, R and L. Stracca (2006), "What is global excess liquidity and does it matter?, ECB Working Paper No. 696. November.

Solnik, B.H (1974), "Why Not Diversify Internationally Rather than Domestically?" Financial Analyst Journal, Vol. 30, pp. 91-135.

Taylor, John B. (2008), "The impact of globalisation on monetary policy", paper presented at the Symposium on "Globalisation, Inflation and Monetary Policy", hosted by the Banque de France. March. Paris.

Uhlig, H. (2008), intervention on "Solvency, systemic risk and moral hazard: where does he central bank's role begin and where does it end?" held at the conference "The ECB and its Watchers X" hosted by the CFS and Goethe University Frankfurt, 5 September, Frankfurt.

Viñals, J. (2000), "Monetary policy issues in a low inflation environment", paper presented for the first Central Banking Conference on "Why price stability?" hosted by the European Central Bank, 2-3 November 2000, Frankfurt.

Winters, C. (2008), "The carry trade, portfolio diversification and the adjustment of the Japanese yen", Discussion papers 2/2008, Bank of Canada.

Woodford, M. (2007), "Globalisation and monetary policy", Paper prepared for the NBER conference on the "International Dimensions of Monetary Policy", June 11-13 2007, Girona, Spain. 
Figure 1

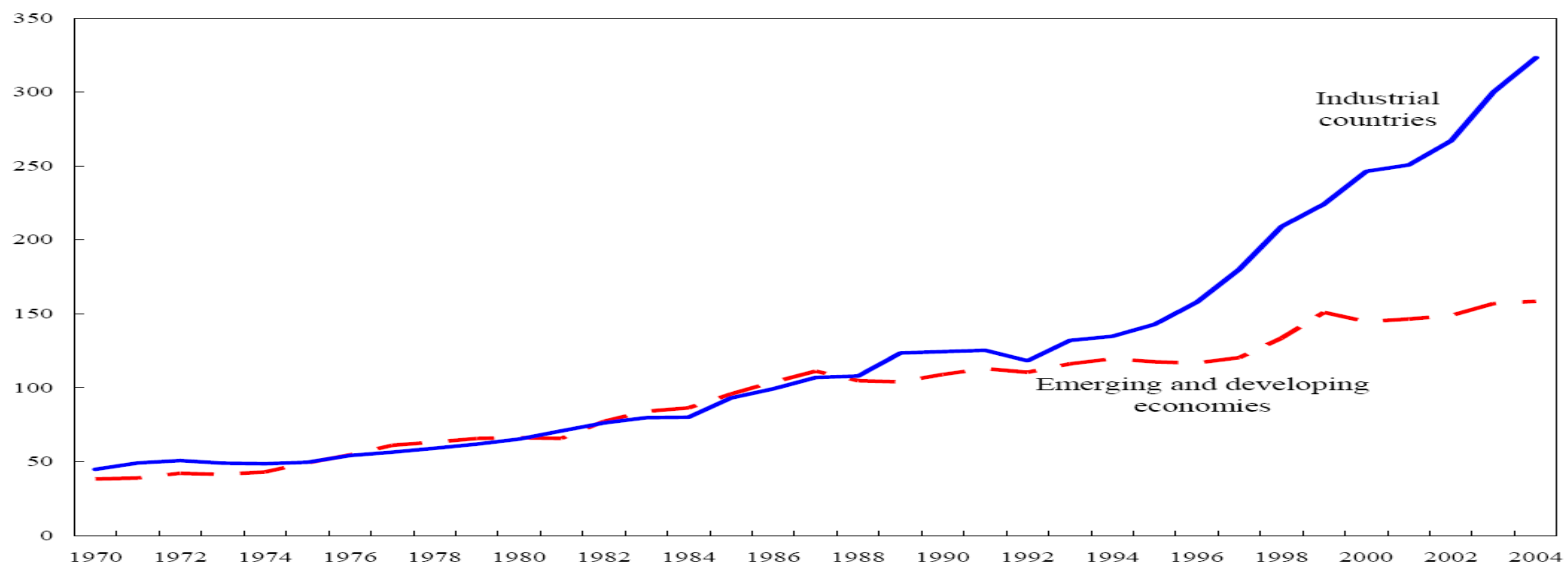

Source: Lane and Milesi-Ferretti (2007). 


\section{Figure II}

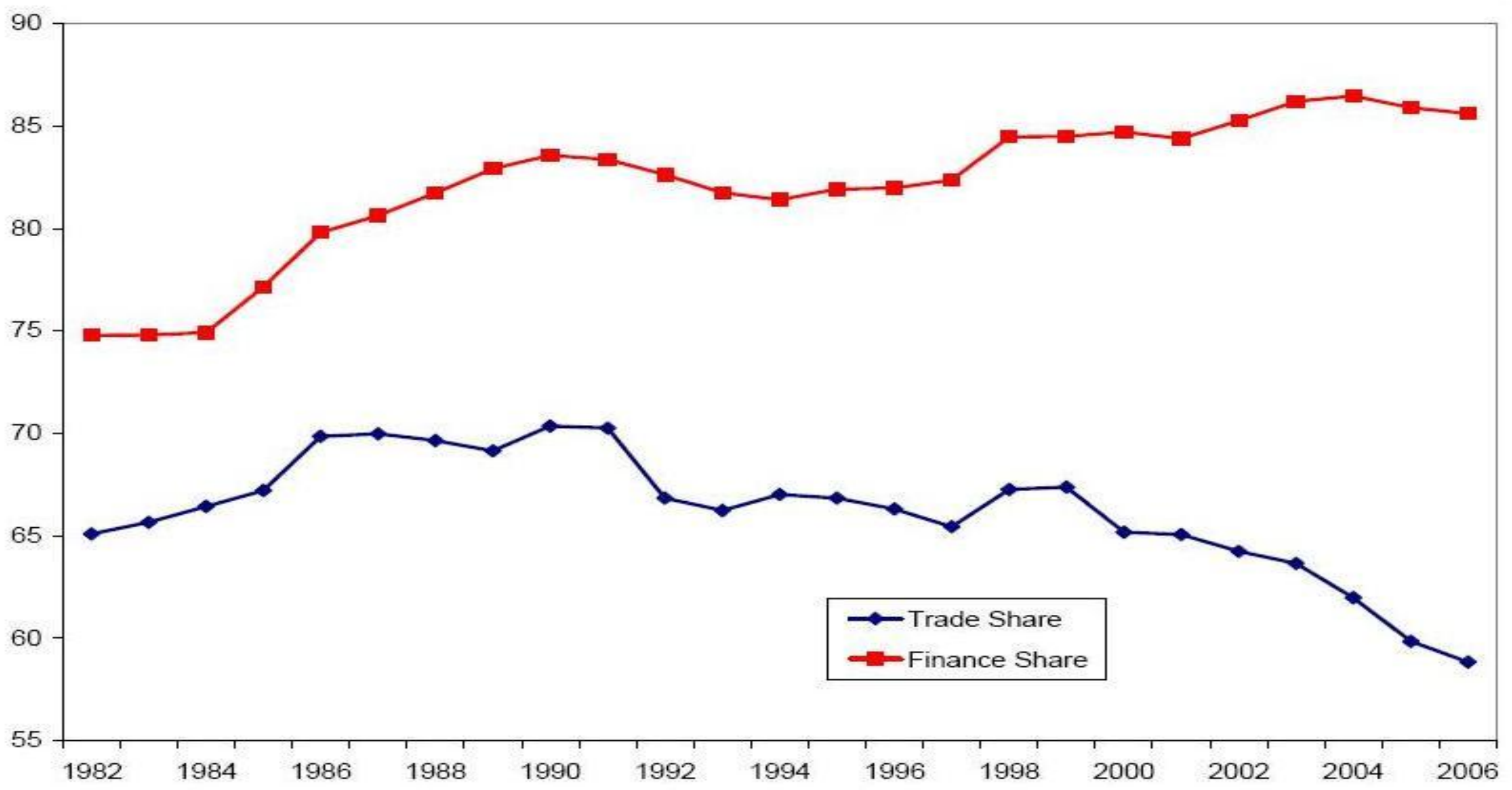

Source: Lane and Milesi-Ferretti (2008). 
Table I

\begin{tabular}{|c|c|c|c|c|c|}
\hline \multirow{2}{*}{$\begin{array}{l}\text { Exchange } \\
\text { rate } \\
\text { regime } \\
\text { Other currency } \\
\text { as legal tender } \\
\text { Currency board }\end{array}$} & \multicolumn{5}{|c|}{ Monetary policy framework } \\
\hline & $\begin{array}{c}\text { Exchange } \\
\text { rate anchor } \\
10(14) \\
13(8)\end{array}$ & $\begin{array}{c}\text { Monetary } \\
\text { target }\end{array}$ & $\begin{array}{l}\text { Inflation } \\
\text { targeting }\end{array}$ & $\begin{array}{c}\text { IMF } \\
\text { Supported }\end{array}$ & Other \\
\hline $\begin{array}{l}\text { Other fixed peg } \\
\text { Single currency }\end{array}$ & $63(21)$ & 2 & & & 1 \\
\hline $\begin{array}{l}\text { Other fixed peg } \\
\text { Composite } \\
\text { Peg with }\end{array}$ & $7(30)$ & & 2 & & \\
\hline Crawling pegs & $6(13)$ & 1 & & & \\
\hline Crawling bands & $1(3)$ & & & & \\
\hline $\begin{array}{l}\text { Managed } \\
\text { floating }\end{array}$ & 48 & 17 & 9 & 7 & 15 \\
\hline $\begin{array}{l}\text { Independently } \\
\text { floating }\end{array}$ & $35(42)$ & 2 & 16 & & 17 \\
\hline Fixed & $105(96)$ & & & & \\
\hline Floating & $83(42)$ & 19 & $25\{7\}$ & & 17 \\
\hline
\end{tabular}

Source: IMF (2007). Pétursson (2000, 2004). Numbers in the table refer to April 2007. In brackets to 1991. In curly brackets to 1997. 


\section{Figure III}

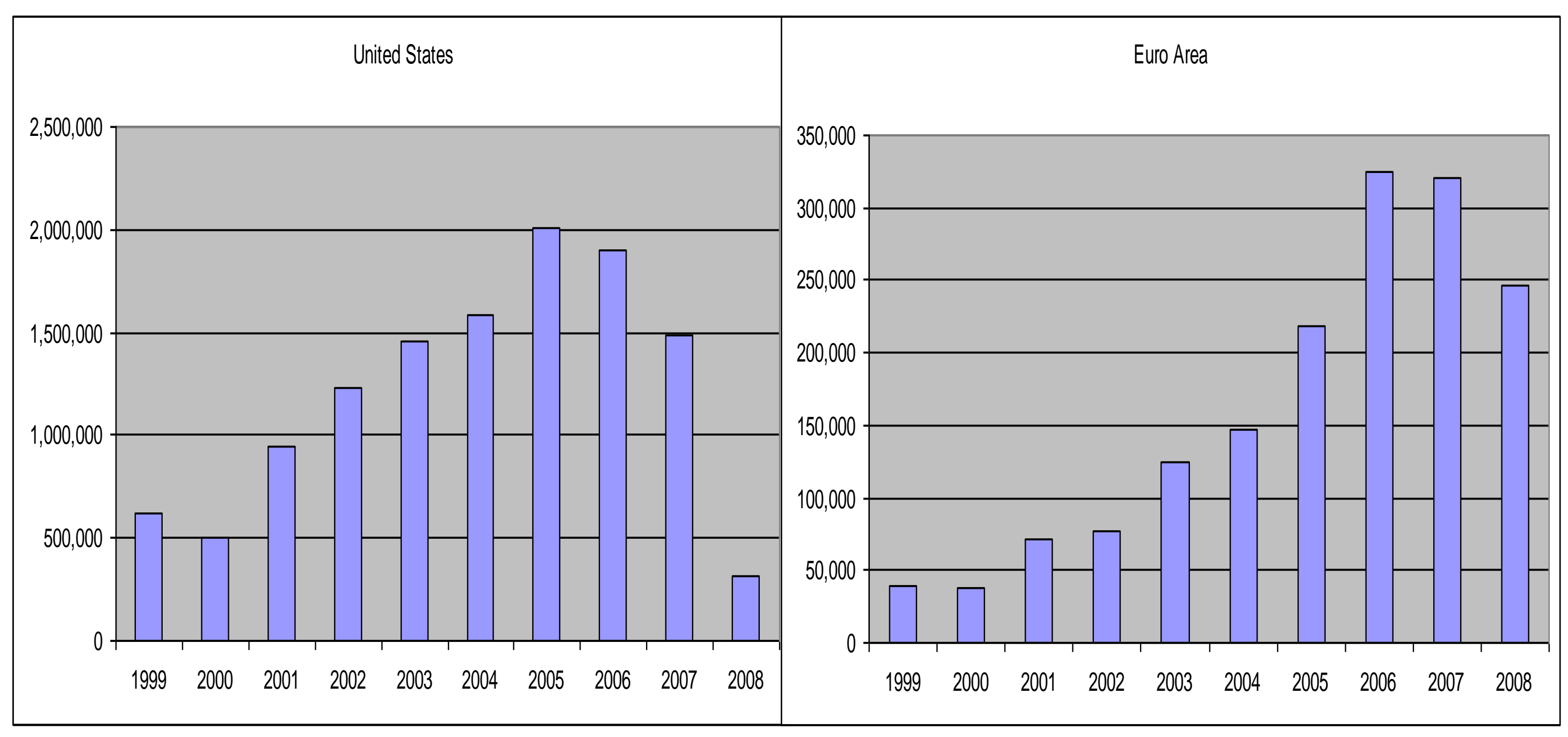

Source: Poloni and Reynaud (2008) 
Figure IV

Global Credit Derivatives Market \$tr

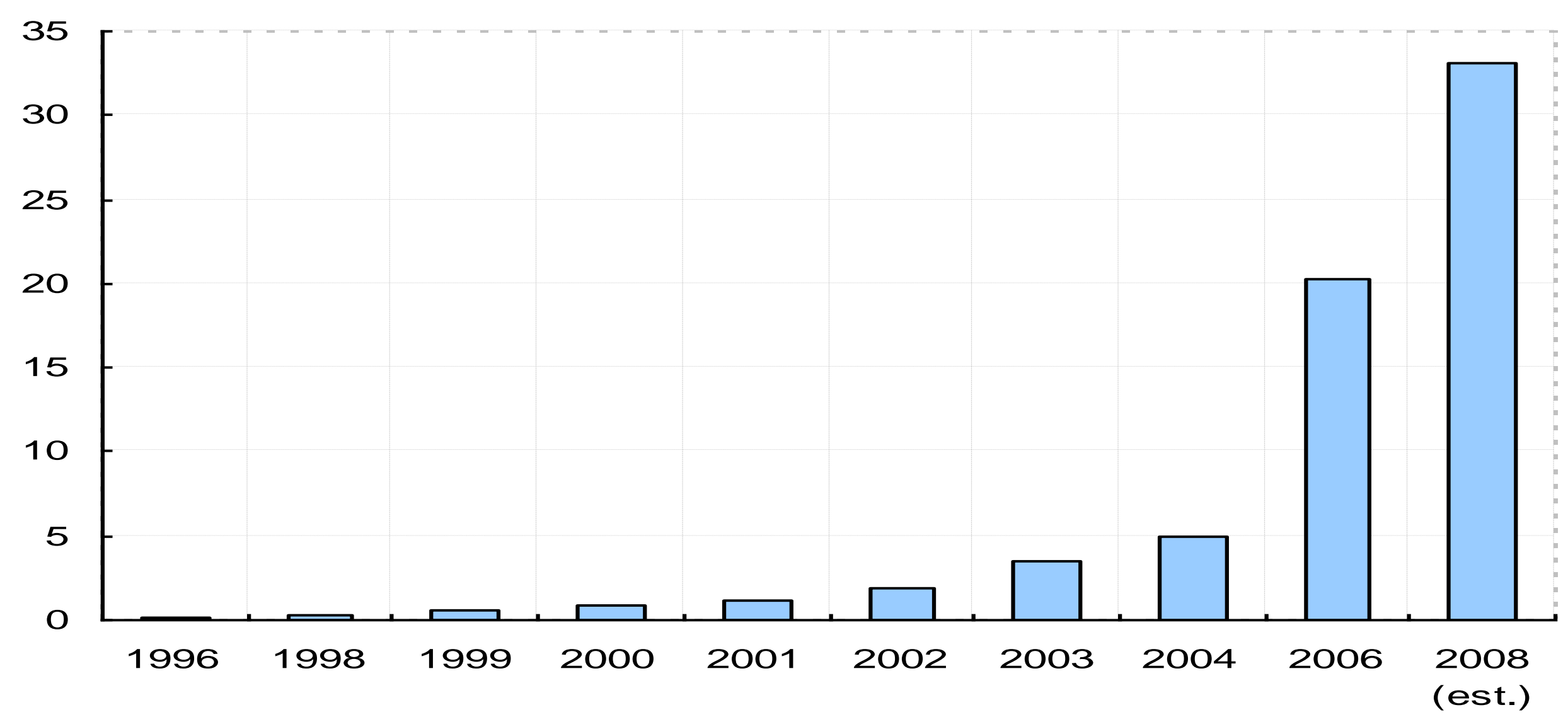

Source: British Bankers Association, (2006). 


\section{Figure V}

The volatility of the US and the euro area stock markets and of the USD/EUR and USD/JPY exchange rates
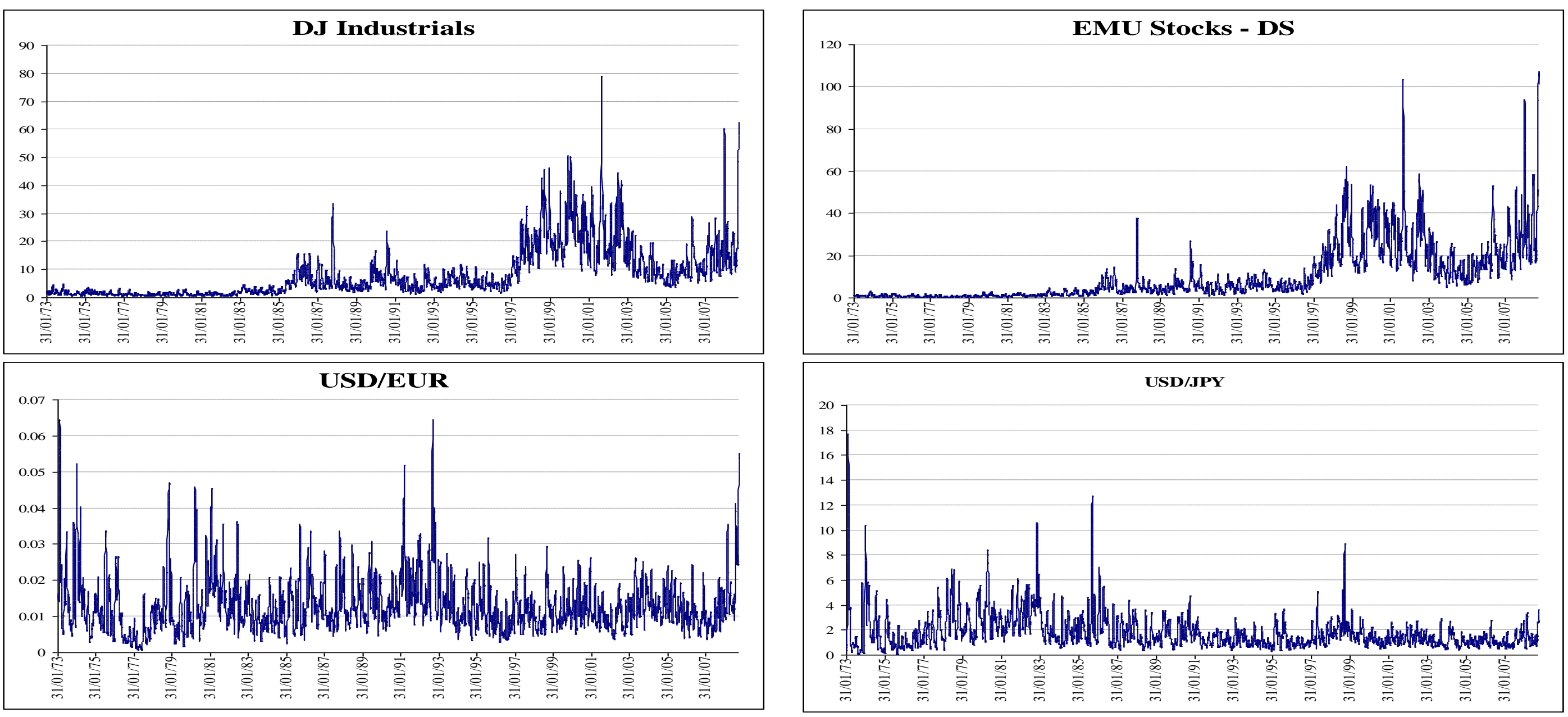

Source: Financial Thompson Datastream and authors'calculation 


\section{Figure VI}

\section{Security dealers and brokers}

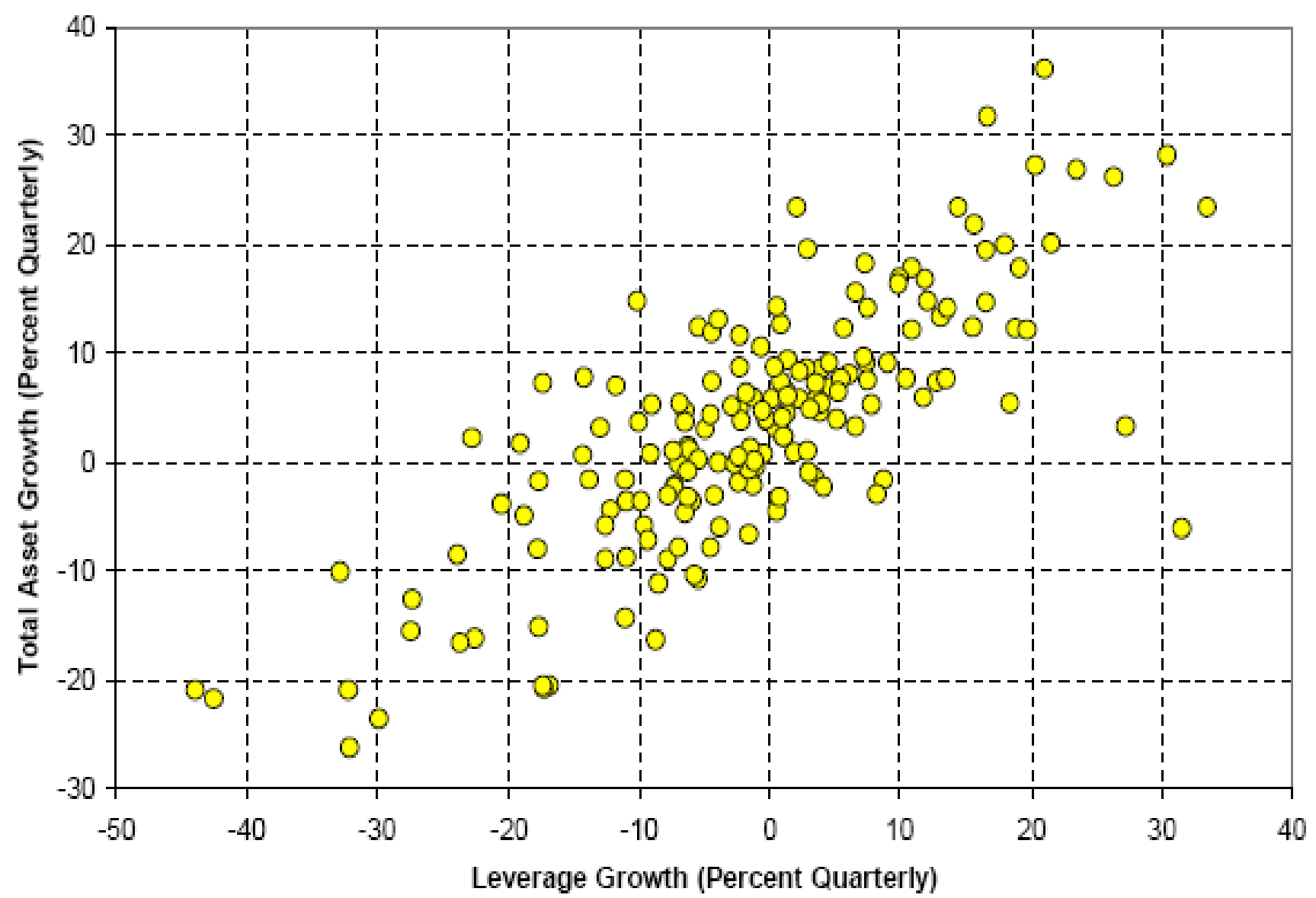

Source: Board of Governors, Federal Reserve, flow of funds, 1963 Q1-2006 Q4.
Non-financial, non-farm corporates

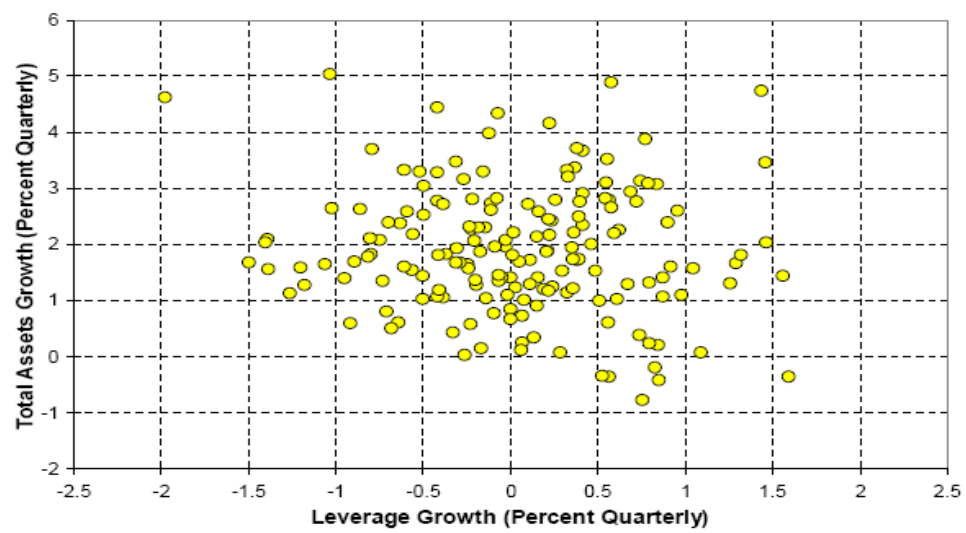

Source: Board of Governors, Federal Reserve, flow of funds, 1963 Q1-2006 Q4.

Commercial banks

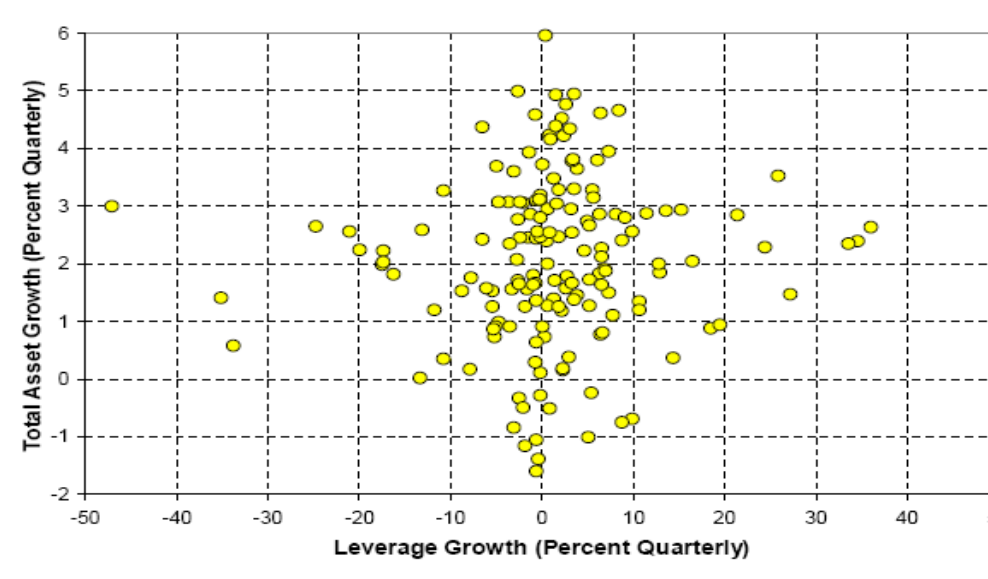

Source: Board of Governors, Federal Reserve, flow of funds, 1963 Q1-2006 Q4.

Source: Adrian and Shin, (2008). 